Portland State University

PDXScholar

Environmental Science and Management

Faculty Publications and Presentations

\title{
The Effectiveness of Vertebrate Passage and Prevention Structures: A Study of Boeckman Road in Wilsonville
}

Catherine E. de Rivera

Portland State University, derivera@pdx.edu

Leslie L. Bliss-Ketchum

Portland State University

Follow this and additional works at: https://pdxscholar.library.pdx.edu/esm_fac

Part of the Ecology and Evolutionary Biology Commons, and the Environmental Sciences Commons Let us know how access to this document benefits you.

\section{Citation Details}

de Rivera, Catherine E. and Leslie L. Bliss-Ketchum. The Effectiveness of Vertebrate Passage and Prevention Structures: A Study of Boeckman Road in Wilsonville. OTREC-RR-10-14. Portland, OR: Transportation Research and Education Center (TREC), 2010. http://dx.doi.org/10.15760/trec.149

This Report is brought to you for free and open access. It has been accepted for inclusion in Environmental Science and Management Faculty Publications and Presentations by an authorized administrator of PDXScholar. Please contact us if we can make this document more accessible: pdxscholar@pdx.edu. 


\title{
S)OTREC
}

FINAL REPORT

\author{
The Effectiveness of \\ Vertebrate Passage \\ and Prevention Structures: \\ A Study of Boeckman Road in \\ Wilsonville
}

OTREC-RR-10-14

September 2010 



\title{
The Effectiveness of Vertebrate Passage and Prevention Structures: A Study of Boeckman Road in Wilsonville
}

\author{
Final Report \\ OTREC-RR-10-14 \\ by \\ Catherine E. de Rivera \& Leslie L. Bliss-Ketchum \\ Portland State University
}

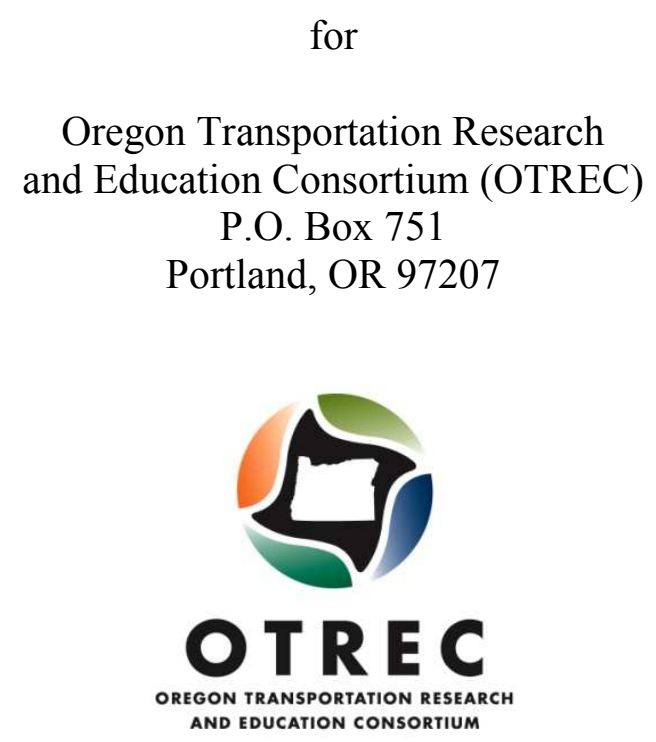

September 2010 


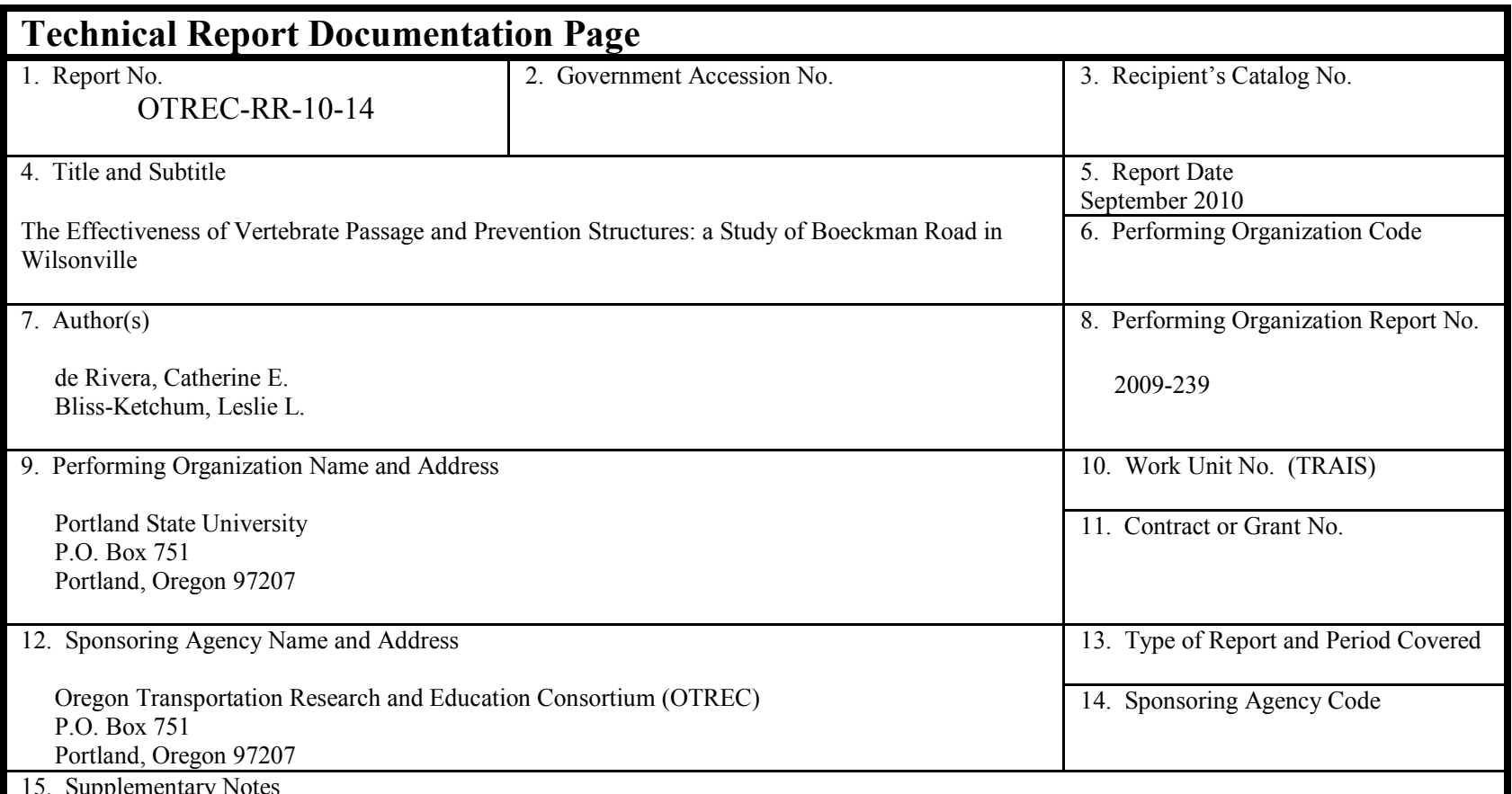

15. Supplementary Notes

\section{Abstract}

One of the most obvious impacts roads have on the natural world is direct mortality to individual animals that attempt to cross roads. A less obvious but likely more important impact of roads on many species is habitat fragmentation. The ability for individuals to travel between subpopulations is the key to genetic diversity as well as ultimately the survival of the species. Considering these impacts and management goals to increase habitat connectivity, increased attention has been given to creating road design that reduces wildlife collisions. Most studies, however, have been in other countries or regions and most focus on connectivity for just one or a few species and rarely in urban settings. This study examines the effectiveness of a variety of under-road passage structures for a community of animals in an urban wetland. Wildlife passage was taken into great consideration in the construction of the Boeckman Road Extension, the new road (2006) in Wilsonville, Oregon, examined in this study. As a result it includes a bridge, two box culverts and eleven round concrete culverts to facilitate wildlife passage as well as a mammal fence atop an amphibian/reptile wall. In order to monitor passage use we used a combination of sand-track monitoring and motion-detect cameras. We compared passage structure use to movement in the habitats surrounding the road by monitoring four habitat transects in addition to the passage structures (Road transect). We also conducted tag and release studies targeted to small mammals. Finally, camera data collected in passage structures were compared to camera monitoring at the end of the exclusionary fencing. A total of 26 species were detected in this study, $73 \%(19)$ of which were found to be using passage structures. $15 \%$ (4) of the identified species were detected on transects but not in passages and $11.5 \%$ (3) were detected in locations other than transects or passage structures. The bridge structure provided passage to the highest number of species (16), followed by the 24 " and 18 " culverts, which had a combined total of 11 species, and lastly the 9x4 culverts, which were flooded, with 2 species detected. Our results indicate that large and medium mammals overall did not use passages less than would be expected based on their local movement in habitats. In pit and Sherman traps sixteen of the 48 small mammals that were captured and tagged were re-caught, but only four of these moved from one transect to another, with two moving away from the road and the other two moving toward and under the road. Of the species detected with cameras at the passage structures and circumventing fencing, excluding small mammals, reptiles and amphibians (139), 19\% (33) were found potentially crossing on the road surface. The proportion of deer detected using over-road crossings (23\%) is of particular concern for driver safety. The bridge structure provided the greatest passage, in not only frequency of crossings but also species present. When maintenance factors, driver safety and species of greatest concern are included, the higher cost of the bridge structure would likely be even further balanced by the benefits. This study highlights the effectiveness and potential problems (and possible fixes) of some of the passage and prevention structures. Including passage and prevention structures such as these in road design is imperative for habitat connectivity and the need for this becomes even more apparent as Oregon's native wildlife face an ever increasing urban landscape as well as the potential impacts of climate change.

17. Key Words
Habitat permeability, road ecology, under-road passage structures, wildlife movement

\section{Distribution Statement}

No restrictions. Copies available from OTREC: www.otrec.us

\begin{tabular}{|l|l|l|l|}
\hline $\begin{array}{l}\text { 19. Security Classification (of this report) } \\
\text { Unclassified }\end{array}$ & $\begin{array}{l}\text { 20. Security Classification (of this page) } \\
\text { Unclassified }\end{array}$ & $\begin{array}{l}\text { 21. No. of Pages } \\
34\end{array}$ & 22. Price \\
\hline
\end{tabular}




\section{ACKNOWLEDGEMENTS}

This project was funded by the Oregon Transportation Research and Education Consortium (OTREC). Special thanks to Kerry Rappold for support, site access and facilitating this research project. Much appreciation for project design input from Dr. Alan Yeakley, Dr. Martin Lafrenz, Dr. Michael Murphy and Dr. Jeff Gerwing. This project also would not have been possible without all the excellent help and support from Joe Bliss-Ketchum, Anneliese Sytsma, Abdullah Hassouneh, Michael Wallace, Amy Dammerall, the amazing students in the de Rivera lab, the Road Ecology class 2008, capstone class of 2009 and all the excellent volunteers and students who assisted.

\section{DISCLAIMER}

The contents of this report reflect the views of the authors, who are solely responsible for the facts and the accuracy of the material and information presented herein. This document is disseminated under the sponsorship of the U.S. Department of Transportation University Transportation Centers Program in the interest of information exchange. The U.S. Government assumes no liability for the contents or use thereof. The contents do not necessarily reflect the official views of the U.S. Government. This report does not constitute a standard, specification, or regulation. 


\section{TABLE OF CONTENTS}

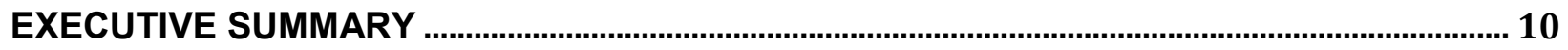

$1.0 \quad$ INTRODUCTION

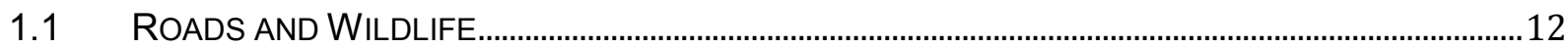

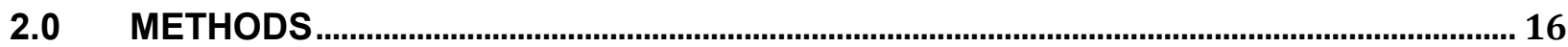

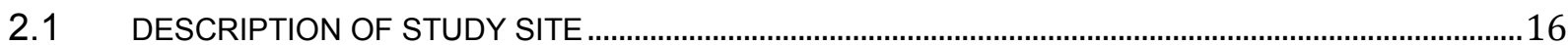

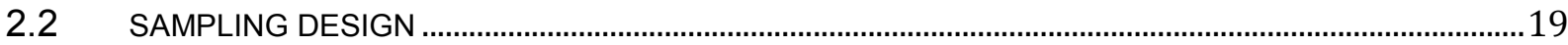

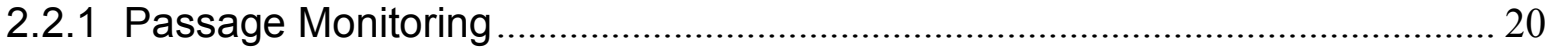

2.2.2 Surrounding Habitat Monitoring ..................................................................... 20

2.2.3 Small Mammal Tag and Release ................................................................... 21

2.2.4 Over-road Crossings .................................................................................... 22

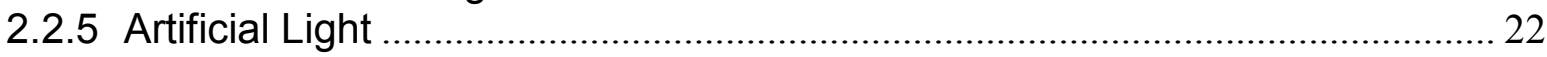

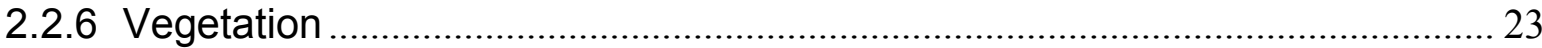

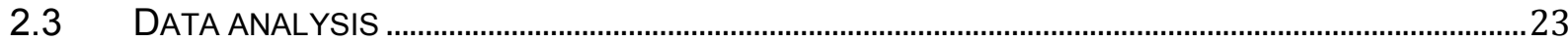

2.4 STUDENT AND VOLUNTEER INVOLVEMENT .................................................................................

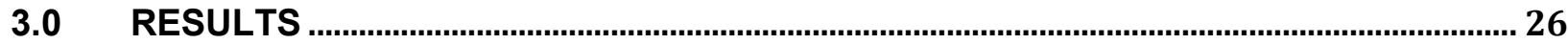

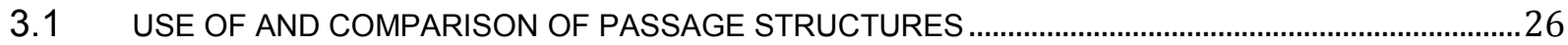

3.2 COMPARISON OF PASSAGE STRUCTURE USE TO SURROUNDING HABITATS................................30

3.3 COMPARISON OF PASSAGE STRUCTURE USE TO OVER-ROAD CROSSINGS ..............................34

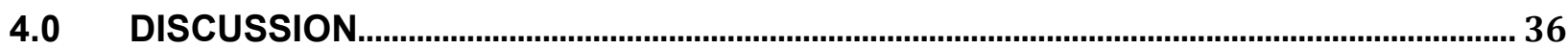

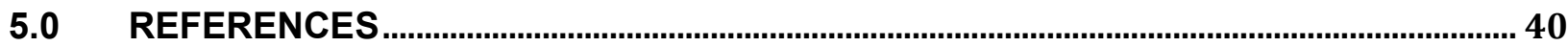




\section{LIST OF TABLES}

Table 3.1: Species detected through motion-detection camera and sand pad tracking using passage structures. Species names are listed under passage structure type and are followed by the number of observations from camera data (July to October 2009) and sand-track data for the bridge (May to June 2009; not needed for the culverts)........................................... 28

Table 3.2: Passage structure conditions as noted on August 31, 2009...................................... 29

Table 3.3: Species detected by motion-detection camera for each transect, listing the number of observations from June to October 2009.......................................................................... 33

\section{LIST OF FIGURES}

Figure 1.1.1: Conceptual model of hypothesized habitat permeability of Boeckman Road, given its many and varied passage structures.

Figure 2.1.1: Aerial photo of a portion of the city of Wilsonville and the study site location (in red box). Note a portion of the Willamette River shown in the southern corner of the photo and Interstate 5 running north-south.

Figure 2.1.2: Aerial photo of Boeckman site during construction. Photo was taken from the east looking west. Research was primarily conducted in the northeastern area of the project (lower right quadrant of photo).

Figure 2.1.3: Results from initial (pre-construction) mammal survey of Boeckman site. Yellow line approximates the location of Boeckman Road post-construction.

Figure 2.1.4: Prevention fencing (red) at Boeckman Road with a total approximate length of

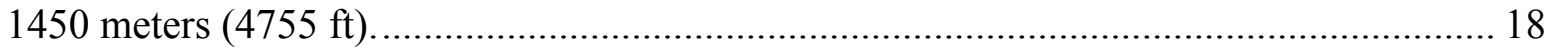

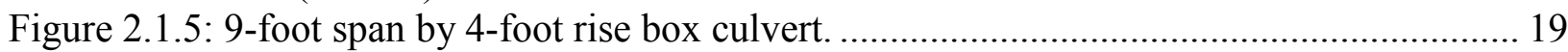

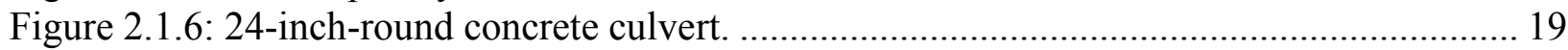

Figure 2.1.7: Bridge and Boeckman Road looking east. ...................................................... 19

Figure 2.1.8: Chain link mammal fence (6 feet) atop the amphibian/reptile wall (2 feet). Note

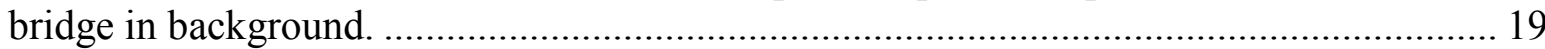

Figure 2.1.9: 18-inch-round concrete culvert. Note amphibian/reptile wall with overhanging lip.

.

Figure 2.1.10: Photo taken from under the bridge passage....................................................... 19

Figure 2.2.1: Reconyx brand motion- detection camera used to monitor wildlife movements.... 19

Figure 2.2.2: Segment of sand-track pad under bridge section 3 …………………………..... 19

Figure 2.2.3: Schematic of transect design at Boeckman study site........................................... 21

Figure 2.2.4: 100M North Station 1 pit trap array. One bucket is located in the center of the array

of plastic sheeting. ........................................................................................................ 22

Figure 2.2.5: Deer mouse about to be released after capture and tagging during mark recapture

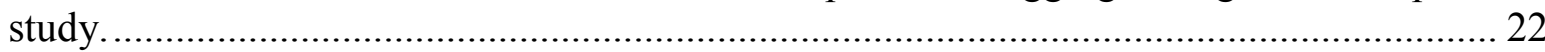

Figure 2.2.6: Fence end monitoring location in relation to fence end (red lines) and nearest passage (24-inch- round concrete culvert)...................................................................... 22

Figure 2.4.1: Volunteers assisting in a variety of field tasks at the Boeckman site...................... 24 
Figure 3.1.1: Total number of individual crossing events captured on motion-detection cameras from July to October 2009 by passage type.................................................................... 26

Figure 3.1.2: Number of individual crossing events captured with both motion-detection cameras (July to October 2009) and sand-pad tracking (May to August 2009) in passage structures.

Figure 3.1.3: Number of species detected to be using passage structures. Includes both camera (July to October 2009) and sand-track data (May to August 2009). .................................... 27

Figure 3.1.4: Sample images from sand-track pad data collection. ............................................ 28

Figure 3.1.5: Number of individual crossing events (camera and sand track data) during a four month monitoring period as a function of passage structure construction cost. Detected crossings were extrapolated to include all passage structures available (includes west half of road project). Assumes all species are of equal value and crossings are limited to the time period of the study (although these structures should last decades), and costs do not factor out construction costs needed for hydrologic connectivity (culverts) or water crossings

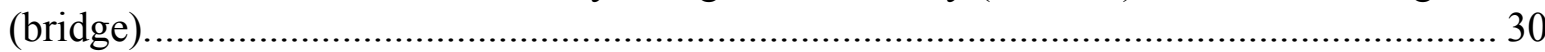

Figure 3.2.1: Percent of animal crossings detected by cameras per transect (excludes small mammals, reptiles, and amphibians due to the low detection probability off-road)............ 31

Figure 3.2.2: Percent of total animal activity per species for the transect study, using camera data and excluding small mammals, amphibians and reptiles (due to low capture probability). The 'Other' category includes Great Blue Heron (0.9\%) Beaver (0.7\%) Virginia Opossum $(0.8 \%)$ Coyote $(0.4 \%)$ Nutria $(0.4 \%)$ and rabbit $(0.3 \%)$................................................... 31

Figure 3.2.3: Total animal activity by transect for the most commonly detected species (camera data): human, house cat, pheasant, raccoon, and deer.

Figure 3.2.4: Total animal activity by transect for the least commonly detected species (camera data): rabbit, Nutria, Coyote, opossum, Beaver, Great Blue Heron (heron), skunk, and Mallard.

Figure 3.2.5: Comparison of percentage of deer crossings at station 1 versus station 5 on the $100 \mathrm{M}$ North transect over time.

Figure 3.3.1: Percentage of animal movements (excluding small mammals, reptiles, and amphibians) detected at the south fence end compared to passage use. 


\section{EXECUTIVE SUMMARY}

The road network crisscrosses our landscape, providing enormous benefits to our society and our expanding transportation needs. Of course, this large web has negative consequences as well, including a myriad of impacts to ecosystems and wildlife. One of the most obvious impacts roads have on the natural world is direct mortality to many animals that try to cross them. A less obvious but likely more important impact of roads on many species is habitat fragmentation. Habitat fragmentation is considered one of the most important factors affecting the local extinction of populations (Wilcox \& Murphy 1985). Roads can severely fragment habitat, disrupting habitat connectivity by bisecting habitats or habitat linkages (Shepard et al. 2008, Parris \& Schneider 2009). Roads serve as a barrier to some species that avoid them due to air and water pollution, noise, changed water flow, etc; others simply cannot get across (Forman et al. 2003, 129). When roads act as a barrier to animal movements, populations may become isolated, reducing the gene pool and increasing susceptibility to environmental disturbance and disease. The ability for individuals to travel between subpopulations is the key to genetic diversity and ultimately the survival of the species (Kautz et al. 2006, Shilling \& Girvetz 2007, Steen et al. 2006, Shepard et al. 2008, Parris \& Schneider 2009). Maintaining and increasing habitat connectivity is already an important need and management goal for wildlife in urban areas and for populations fragmented by roads (Girvetz et al 2008, FitzGibbon et al. 2007).

Considering these impacts, increased attention has been given to creating road design that reduces wildlife collisions. Design approaches include directing wildlife to passage structures that span the road and erecting fencing to prevent access to the road surface. This study provides a test of the assumption that plentiful passage structures combined with prevention structures will reduce the barrier effect of a road to near zero, allowing complete habitat permeability for species in an urban wetland community. In the city of Wilsonville, OR, a road construction project known as the Boeckman Road Extension was initiated in 2006 and consisted of approximately $1.6 \mathrm{~km}$ of new road. Wildlife passage was taken into great consideration in the construction of the Boeckman Road Extension. As a result it includes a bridge, two box culverts, and 11 round concrete culverts to facilitate wildlife passage as well as a mammal fence and amphibian/reptile wall. Just as it is important to install, it is equally important to assess the effectiveness of these structures. The Boeckman site provides a unique opportunity to do such an assessment with multiple passage and prevention structures in one location.

In order to monitor passage use, a combination of sand-track monitoring and motion-detection cameras was used. In order to conduct a comparison of passage structure use to movement in the habitats surrounding the road, four habitat transects were monitored along with the passage structures (road transect). To compensate for the low probability of detection of movements by small animals along habitat transects, tag-and-release studies were conducted to targetsmall mammals. In addition, camera data collected in passage structures were compared to camera monitoring at the end of the exclusionary fencing.

A total of 26 species were detected in this study: 73\% (19) were found to be using passage structures; $15 \%$ (four) were detected on transects but not in passages and $11.5 \%$ (three) were 
detected in locations other than transects or passage structures. The bridge structure provided passage for the highest number of species (16), followed by the 24 inch and 18 inch culverts, which accomodated a combined total of 11 species. Lastly, the 9-foot-by-4-foot culverts, which were flooded, accounted for two species detected. Results indicate that large and medium mammals overall did not use passages less than would be expected based on their local movement in habitats. In pit and Sherman traps, 16 of the 48 small mammals that were captured and tagged were re-caught, but only four of these moved from one transect to another. Two moved away from the road and the other two moved toward and under the road. Of the 139 animals detected with cameras (excluding small mammals, reptiles and amphibians) at the passage structures and at the edge of the fencing, 19\% (33) were found skirting the fence and heading for the road surface. The proportion of deer detected crossing over the road $(23 \%)$ is of particular concern for driver safety.

It is expected that as planted vegetation matures, the movements of species over the landscape will change, with species that prefer cover being more likely to use new locations. In comparison to studies on usage of passages installed as retrofits, species use of passages at Boeckman was instantaneous, with some passage occurring even during construction. While some species were not evident immediately, species use of habitat and road structures increased as construction concluded and as vegetation has matured. The utilization of fencing has no doubt greatly increased the success of the Boeckman road site. Fencing coupled with adequate passage structures prevents animal-vehicle collisions while maintaining essential habitat connections for wildlife (Clevenger et al. 2001, Dodd et al. 2004, Glista et al. 2009).

To maintain and enhance the functionality of passages, other than the bridge, the issues of standing water and potential for clogging will need to be periodically assessed and, in the case of the 9-by-4 culverts, corrected. The bridge does not require maintenance for clogging or standing water due to its high clearance and ability to drain at a similar rate to surrounding habitat. The lack of these costly maintenance needs and high diversity of species use provides rationale for the increased upfront cost associated with bridge passages.

The bridge provided the greatest passage, not only in frequency of crossings but also in the number of species crossing it. If maintenance factors, driver safety and species of greatest concern were included, the higher cost of the bridge would likely be even further balanced by the benefits. All aspects of this study are being continued, but it is expected that updated results based on larger sample size and greater time since construction will continue supporting all conclusions presented here. The importance of passage and prevention structures such as these, and of researching them, becomes even more apparent as Oregon's native wildlife faces an everincreasing urban landscape as well as the potential impacts of climate change. 


\subsection{INTRODUCTION}

\subsection{ROADS AND WILDLIFE}

The road network crisscrosses our landscape, providing enormous benefits to our society and our expanding transportation needs. Of course, this large web has negative consequences as well, including a myriad of impacts to ecosystems and wildlife. One of the most obvious impacts roads have on the natural world is direct mortality to many animals that attempt to cross them. Cars collide with large animals over one million times each year in the U.S. and even more frequently with small ones (Conover et al. 1995). Car collisions with large animals cause human injury more than $4 \%$ of the time and sometimes death; kill $92 \%$ of the animals; and create damagerelated expenses totaling over $\$ 8$ billion yearly (Allen \& McCullough 1976, Conover et al. 1995, Huijser et al. 2007). In the U.S., approximately 150 human fatalities and $\$ 1.1$ billion in property damage result annually from deer-vehicle collisions alone (IIHS 2005). It is far more difficult to assess mortality rates for wildlife that do not cause damage to vehicles, such as small mammals and reptiles. Therefore, it is often unclear if the roadkill rate exceeds that of natural causes of death in a population, and whether it is high enough to send a population into decline. Nonetheless, road mortality has been implicated as a major threat to 21 federally listed threatened or endangered species (Huijser et al. 2007). Mortality from roads will have variable impacts depending on the population size, reproductive rate and generation time of each species.

A less obvious but likely more important impact of roads on many species is habitat fragmentation. Habitat fragmentation is considered one of the most important factors affecting the local extinction of populations (Wilcox \& Murphy 1985). Roads can severely fragment habitat, disrupting habitat connectivity, by bisecting habitats or habitat linkages (Shepard et al. 2008, Parris \& Schneider 2009). Roads reduce habitat connectivity for many reasons. Already mentioned is road mortality, which may be very high for some species like amphibians and turtles (e.g., Glista et al. 2007). Roads serve as a barrier to some species that avoid them due to pollution, noise, changed water flow, etc; others simply cannot get across (Forman et al. 2003, 129).

When roads act as a barrier to animal movements, populations may become isolated, reducing the gene pool and increasing susceptibility to environmental disturbance and disease. The ability for individuals to travel between subpopulations is key to genetic diversity and ultimately the survival of the species (Kautz et al. 2006, Shilling \& Girvetz 2007, Steen et al. 2006, Shepard et al. 2008, Parris \& Schneider 2009). As human development increases and as we face the unknown future of climate change, the need for functional ecosystems and viable connections between habitats becomes even more vital. Therefore, maintaining and increasing habitat connectivity is already an important need and management goal for wildlife in urban areas and for populations fragmented by roads (Girvetz et al. 2008, FitzGibbon et al. 2007). 
Considering these impacts, increased attention has been given to creating road design that reduces wildlife collisions. Design approaches include directing wildlife to passage structures that span underneath the road and erecting fencing to prevent access to the road surface. One of the most effective mitigation techniques to reduce animal-vehicle collisions is lining the road with fencing (Clevenger et al. 2001, Huijser et al. 2007). However, installing fencing can eliminate habitat connectivity for wildlife and must be combined with installing passage options. Fragmentation can be at least partially mitigated and risk of collision to drivers and wildlife decreased by adding wildlife passages, with accompanying fences, and restoring or protecting wildlife corridors to increase landscape permeability. A fully permeable landscape is one that has low resistance to animal movement and allows animals to travel freely throughout their home ranges year round. It also allows migrating animals to access important habitats. Under-road passages have proven effective at increasing permeability for many mammals, especially larger species (Bissonette \& Cramer 2007).

Implementing wildlife passage and prevention structures can result in increased costs for both construction and maintenance. In order to use limited funds most appropriately and efficiently, the effectiveness of different types of wildlife passage structures for different species and in different habitats and road types must be studied. Through scientific assessment, features of passage structures could be modified to streamline costs and decrease wildlife aversion.

Despite the importance of effective animal passages to people and animals, few research studies address Oregon's needs . Studies on the topic have been increasing in recent years, but primarily have been conducted in Europe (Langton 1989, Friedman 1997) or Canada (Clevenger \& Waltho 2000), where the use of passage structures is more common and is implemented to aid annual migrations and assist in species recovery. Without data that indicate the baseline animal presence and movement in the area it is difficult to assess whether the amount and diversity of animals using the passage is representative. Therefore, in addition to need for local studies on wildlife use of passage structures, there is a need to identify wildlife usage of passage structures relative to their presence in the vicinity of the road.

Animal usage of passageways can be limited by avoidance of the general road area, lack of approach to the passage structures themselves (perhaps not on a traveled route), or wariness of entering the under-road passage structures. Noise and human activity could contribute to general wildlife avoidance of the road independent of possible issues with the passage structures. For example, coyote use of passage culverts in Canada was found to be negatively correlated with traffic volume (number of vehicles per time), road width, and noise (Clevenger et al 2001). Arthropods, small mammals, large mammals, forest birds, and grassland birds have all been shown to avoid roads (Forman \& Alexander 1998). Similarly, Shepard et al. (2008) found that two species of box turtle and one species of rattlesnake crossed roads significantly less than predicted by chance, suggesting strong road avoidance. For animals that approach roads, the presence of fencing can funnel them toward passage structures, thereby increasing the likelihood that they encounter the structures.

Animals' entry into a passage structure may be affected by variables such as light penetration within the passage, line of site through the passage, physical characteristics of the structure, vegetation cover and placement. For instance in Portugal, Ascensao and Mira (2007) noted a positive effect on genet (a ferret-like predator) crossings for passages where vegetation covered 
the culvert. In California $\mathrm{Ng}$ et al. (2003) found that presence of suitable habitat on both sides of the road and passage dimensions were the most important factors influencing wildlife use. Multiple studies conducted in Spain found small mammals preferred small diameter, short culverts with vegetation cover nearby (Forman 2003). Passage use also may be low due to small home ranges and small-scale movement patterns, which simply would mean the roadway did not bisect key habitats.

This study tests the assumption that plentiful passage structures combined with prevention structures will reduce the barrier effect of a road to near zero, allowing complete habitat permeability (Figure 1.1.1). It builds on previous research by addressing animal use of passages for the whole community of terrestrial vertebrates, and by examining the use of passages and habitat use and movement in the surrounding area. It also provides information relevant to Oregon fauna and roadways. By comparing the abundance and distribution of animals in the areas surrounding the road with passage use data, a measure of successful passage use can be determined. The study design also allows identification of the cause of any lower-than-expected use, whether lower use is due to lack of approach to the road, lack of approach to the passageways, or lack of entrance into the passageways.

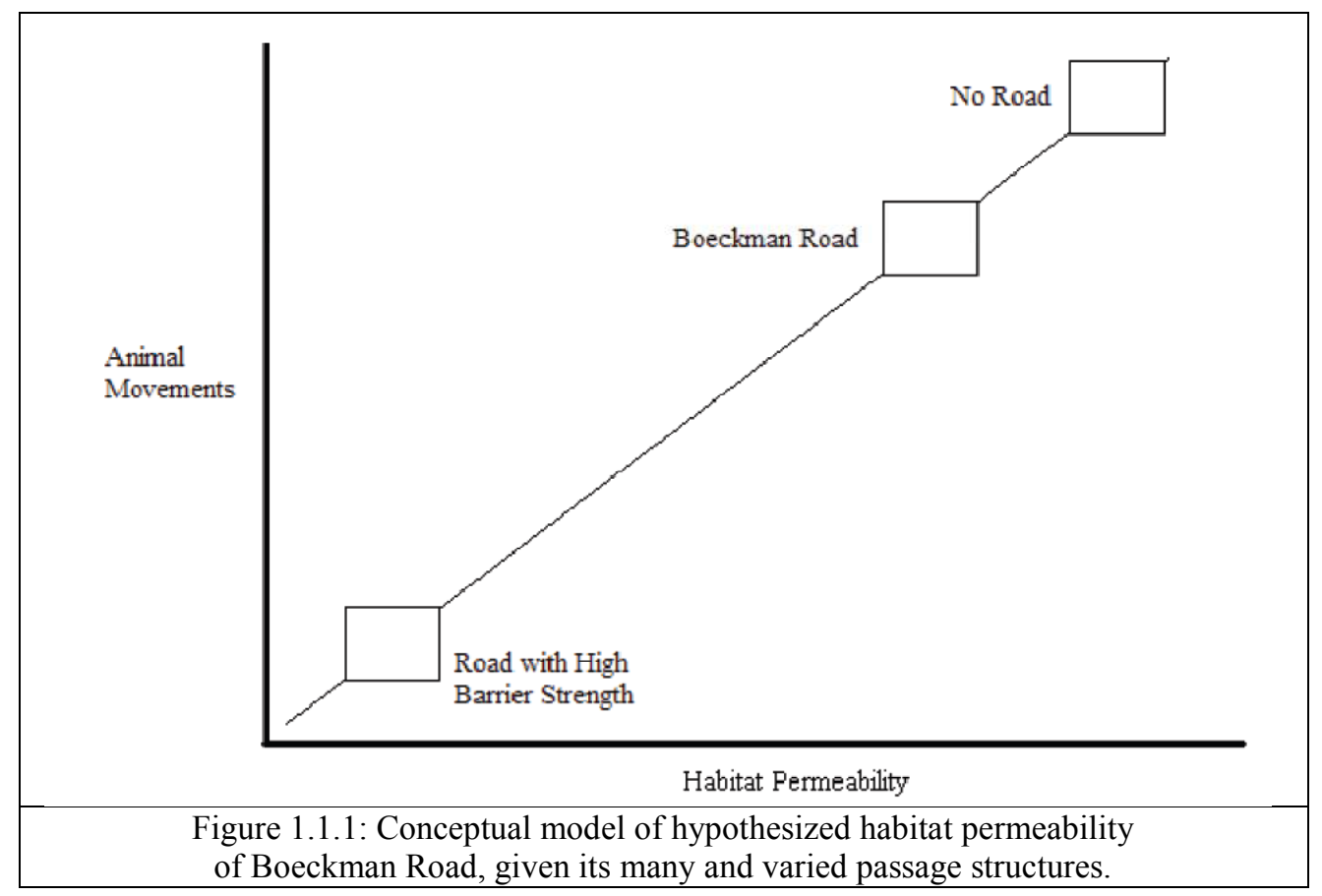




\subsection{METHODS}

\subsection{DESCRIPTION OF STUDY SITE}

In the city of Wilsonville, OR, the Boeckman Road Extension was initiated in 2006 and consisted of approximately $1.6 \mathrm{~km}$ of new road connecting what was previously the dead end of Boeckman Road with Tooze Road (Figure 2.1.1). The road itself consists of three lanes approximately 13.5 meters $(44.5 \mathrm{ft})$ across and narrows over the bridge section to two lanes approximately 11.5 meters $(38 \mathrm{ft})$ across. Along the length of the road extension there is a sidewalk averaging 4 meters $(13.5 \mathrm{ft})$ across. The estimated project cost totaled $\$ 17$ million, with wildlife passage and prevention structures costing of $\$ 3$ million, 17\%, of the total. The bridge accounted for the vast majority of this cost ( $\$ 2.5$ million) followed by prevention fencing $(\$ 300,000)$ and box and round culverts combined $(\$ 255,000)$. Boeckman Road was officially opened to traffic in June 2008.

A one week study of traffic volume and speed was conducted from June $12^{\text {th }} 2010$ to June $18^{\text {th }} 2010$ by HDR Engineering Inc. The average daily traffic (ADT) for Boeckman Road during that timeframe was 2952 vehicles per day, 1605 in the westbound direction and 1347 in the eastbound direction.

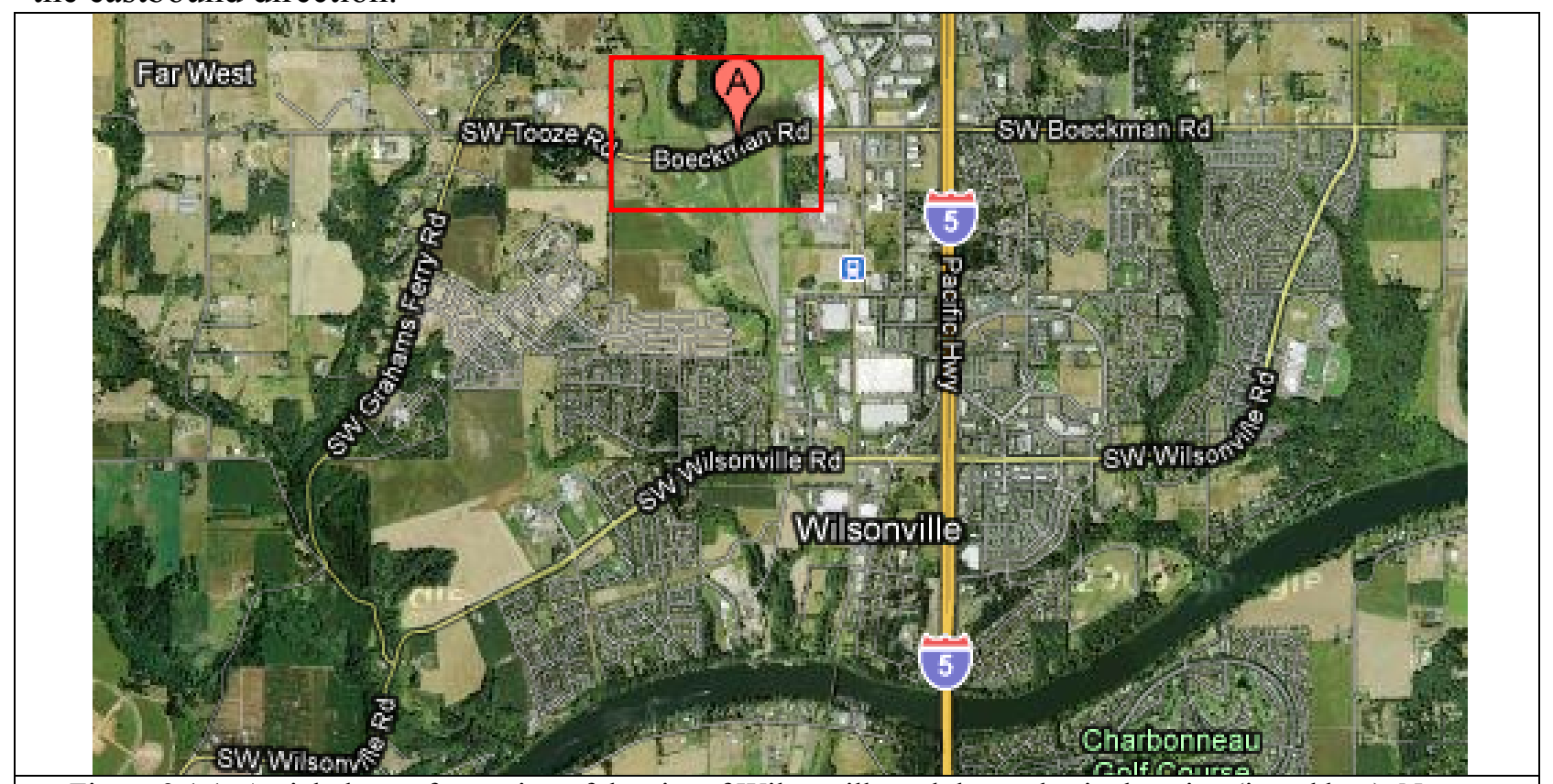

Figure 2.1.1: Aerial photo of a portion of the city of Wilsonville and the study site location (in red box). Note a portion of the Willamette River shown in the southern corner of the photo and Interstate 5 running north-south.

The road extension spans a portion of the Coffee Lake Creek wetlands and is bordered by private farms (west and south), a forested upland island (north) and a corporate park (east) (Figure 2.1.2). The 6,200-acre Coffee Lake Creek drainage basin is a tributary of the Willamette River, which is located approximately $2.5 \mathrm{~km}$ south of the study site. Most of the site and surrounding areas are or have been used for agricultural production. These areas have been fallow for some time and, previous to enhancement work conducted through the Boeckman Extension project, 
were dominated by reed canary grass. North of the site is an upland forested island supporting Douglas fir and Madrone, among other native tree, shrub and herbaceous vegetation. Northeast of the alignment is an emergent shrub-scrub wetland complex partially owned by the local regional government body, Metro; Metro plans to restore these and other wetlands within the basin.

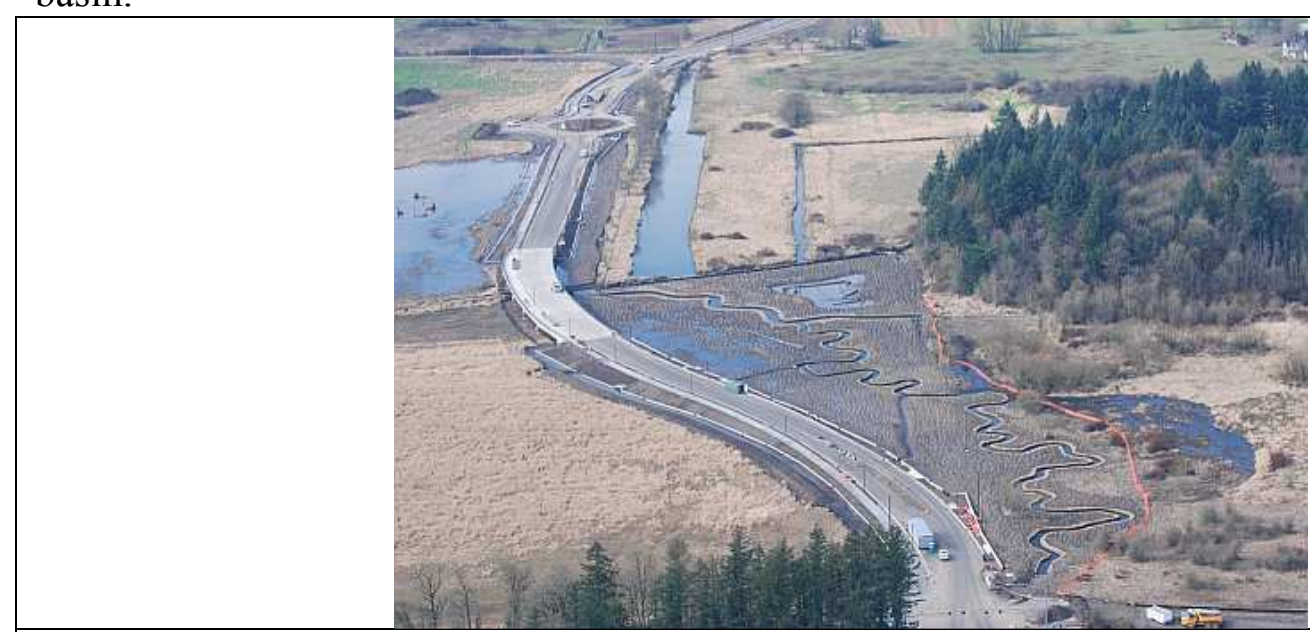

Figure 2.1.2: Aerial photo of Boeckman site during construction. Photo was taken from the east looking west. Research was primarily conducted in the northeastern area of the project (lower right quadrant of photo).

A mammal wildlife survey was conducted by Terry Kem at the Boeckman road site in March 2004, prior to construction (Figure 2.1.3). This survey found evidence of black-tailed deer, raccoon, coyote, nutria, beaver, mink, and river otter. Adjacent lands are considered prime redlegged frog habitat. In addition, the presence of a pond and a forested upland island was noted as essential habitat for the western pond turtle.

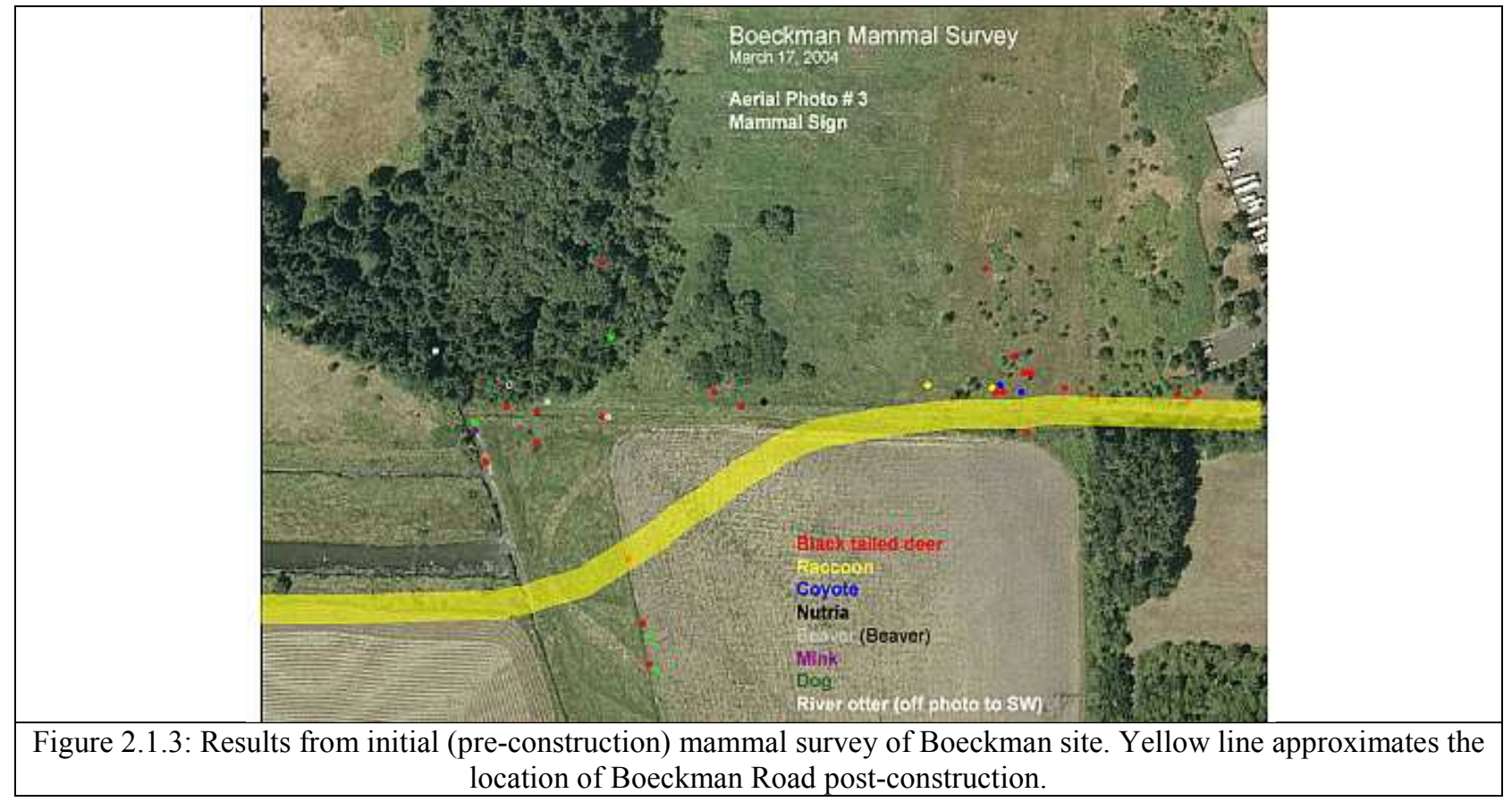


Wildlife passage was taken into great consideration during the extension project. As a result, it includes a bridge ranging from five to nine feet tall and approximately 400 feet in length; two box culverts with a 9 foot span and 4 foot rise; and five 24 -inch and six 18 -inch-round concrete culverts to facilitate wildlife passage (Figures $2.1 .4-2.1 .10$ ). These features also are designed to help prevent disruption of hydrologic function of the wetland. In addition, prevention fencing is part of the road design and includes a two-foot concrete amphibian wall, with an overhang, topped by a six-foot-tall mammal fence to prevent animals from entering the road surface (Figure 2.1.7 and 2.1.8). The fencing has approximate length of 1450 meters (4755 ft) (Figure 2.1.4). The width of the area over the road within the fencing averages 27 meters $(88 \mathrm{ft})$.

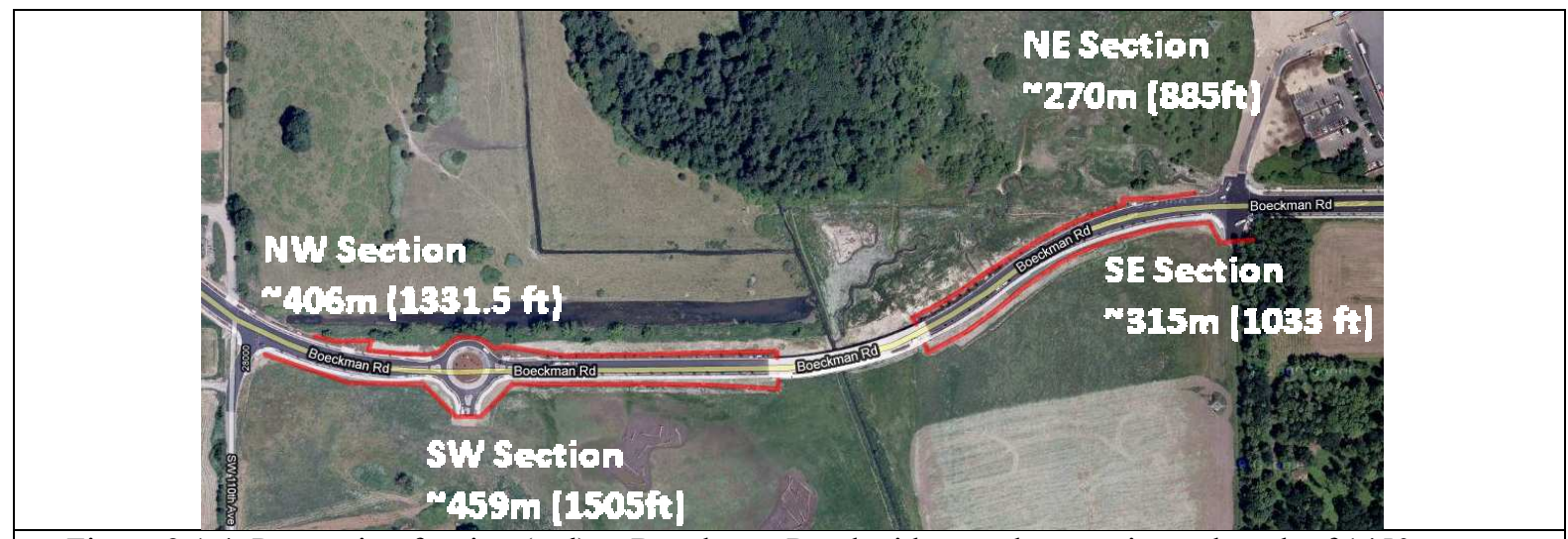

Figure 2.1.4: Prevention fencing (red) at Boeckman Road with a total approximate length of 1450 meters $(4755 \mathrm{ft})$.

Both 9 by 4 culverts and three of the four 24 -inch culverts include grating that allows natural light penetration. In addition to incorporating wildlife passage and prevention structures, the project required restoration and enhancement of the wetland. This enhancement included adding meanders to what had been a straight drainage ditch and planting, in 2008, willows and other vegetation. 


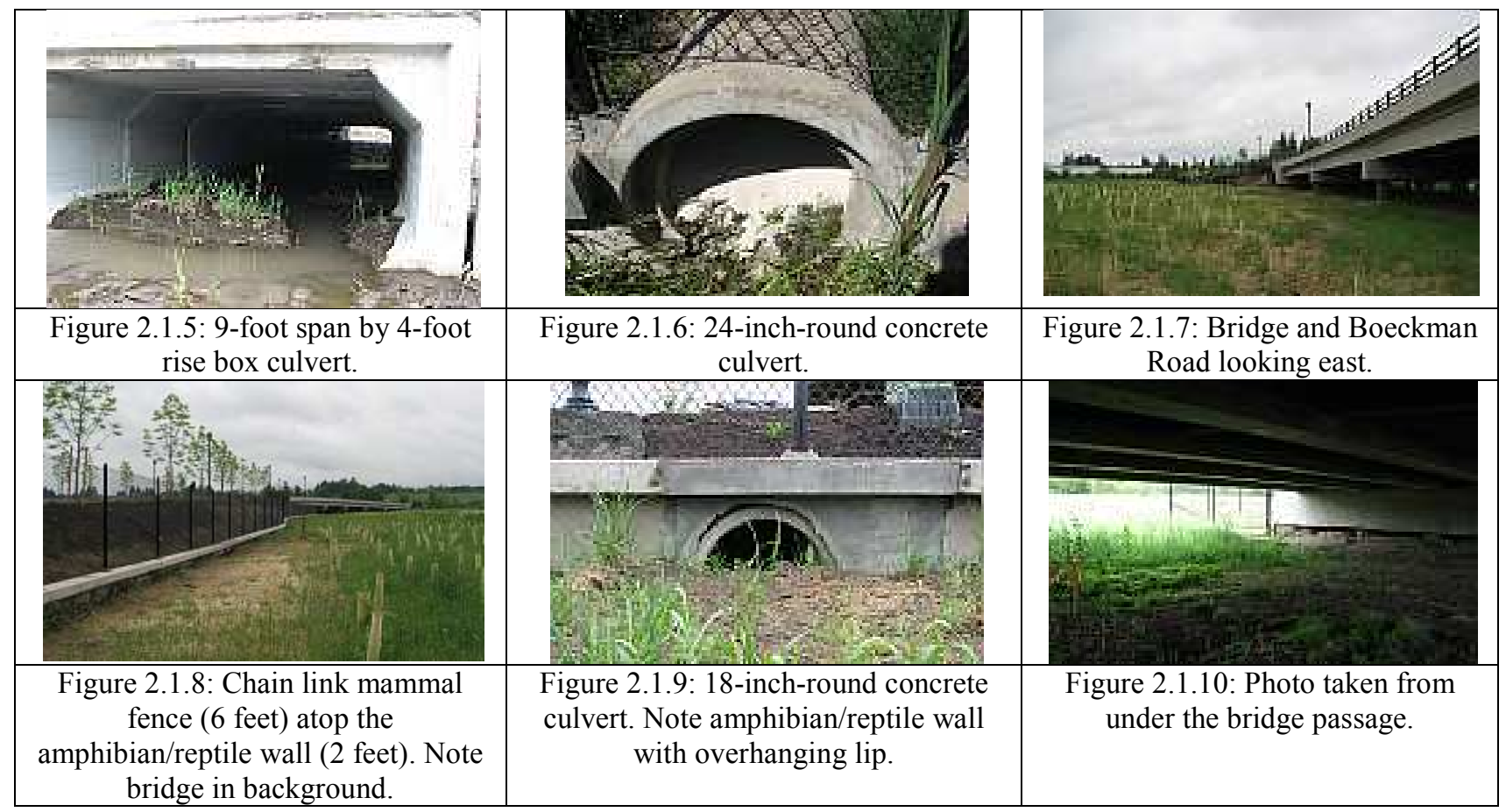

\subsection{SAMPLING DESIGN}

In order to monitor passage use, a combination of sand-track monitoring and motion-detection cameras was used (Figure 2.2.1 and 2.2.2). Sand-track monitoring was conducted on a weekly basis from May to September 2009 under bridge sections 2 and 3 to account for small animals not likely to be captured by the cameras. Similar tracking was conducted in 2008 as well, but is not reported here due to the temporal mismatch with the camera data.

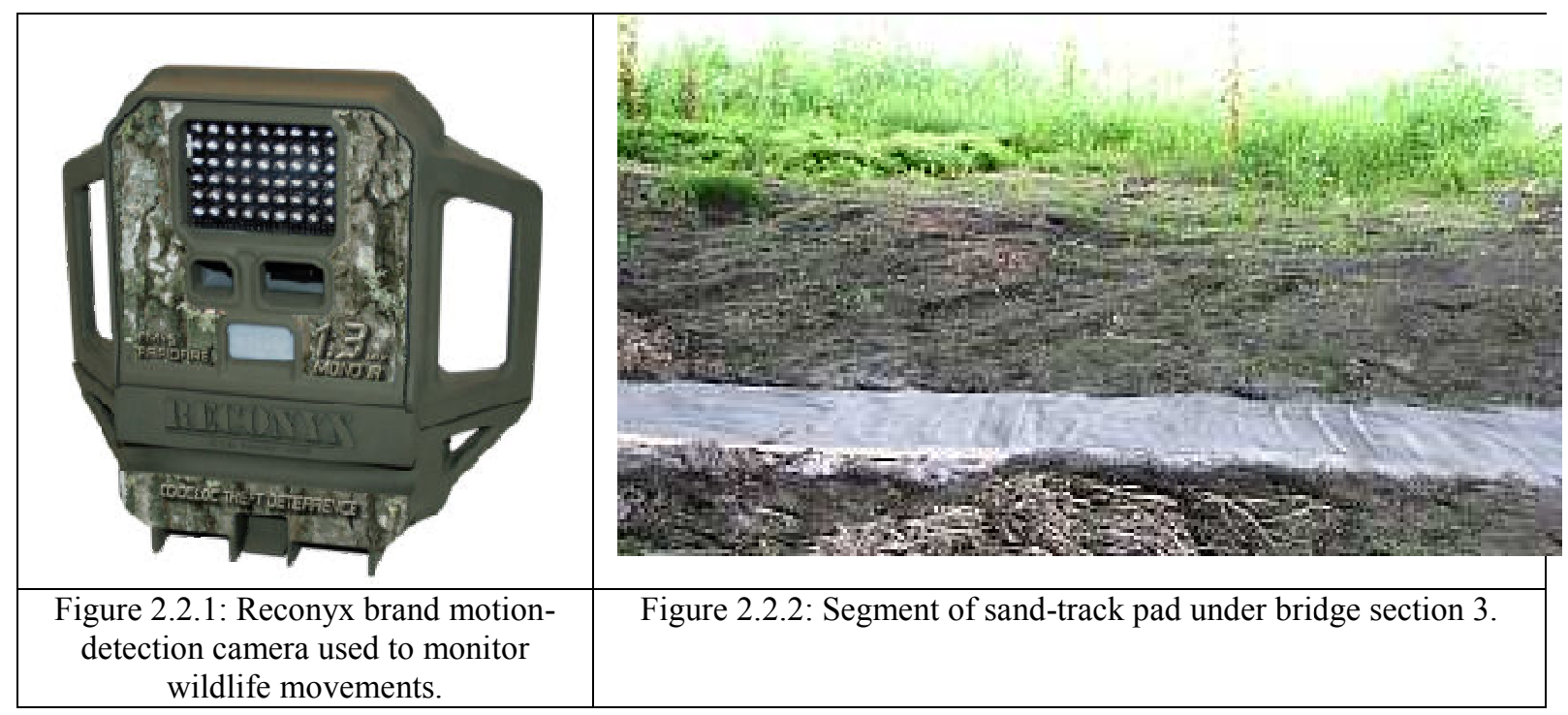




\subsubsection{Passage Monitoring}

Reconyx brand model RM45 motion-detection, infrared cameras were used to identify vertebrate species using the passage structures as well as to compare passage use to movement across the landscape. Each camera in the surrounding habitat was mounted on a metal fence post, approximately one-third to one-half meter from the ground surface, with a slight angle downward to limit false triggering. Cameras in small passage structures (18-inch and 24-inch) were mounted directly to the concrete and were similarly angled but positioned more closely to the ground (approximately $15 \mathrm{~cm}$ ). The cameras in these culverts therefore were effective at detecting movement of small animals. Cameras located under the bridge were mounted to posts and angled only slightly downward to capture medium and large animals moving across the entire span. As a consequence, cameras under the bridge were much less capable of capturing small animals such as mice, voles, snakes and frogs. To supplement the bridge camera data, sand-track pads were established under bridge sections 2 and 3 and were monitored weekly. Camera flash cards were exchanged and batteries checked on a weekly basis. Collected cards were brought back to the lab and downloaded. Species were then identified and entered into an Access database. Animals' ability to traverse and the presence of standing water near passage structures were assessed and documented on 31 Aug. 2009.

\subsubsection{Surrounding Habitat Monitoring}

In order to conduct a comparison of passage structure use to movement in the habitats surrounding the road, four habitat were monitored along with the passage structures (road transect) (Figure 2.2.3). These transects were set at varying distances from the road: $100 \mathrm{M}$ North, 25M North, 2M North, Road and 2M South. Each transect contained nine stations spaced 30 meters apart, which approximates the distances between passage structures along the road. The bridge passage was divided into three sections, also approximately 30 meters apart. Data were collected at stations using a randomized block design, blocked by time. For each transect, including the road transect, data were collected for three randomly selected stations or passages for seven consecutive days, followed by a second and a third set of three randomly selected stations, without replacement. All nine stations were sampled in a 2-day period. This sampling scheme was repeated five times with new randomized orders from 8 July 2009 until 21 Oct. 2009. Cameras were mounted to posts and positioned similarly to those under the bridge passage. 


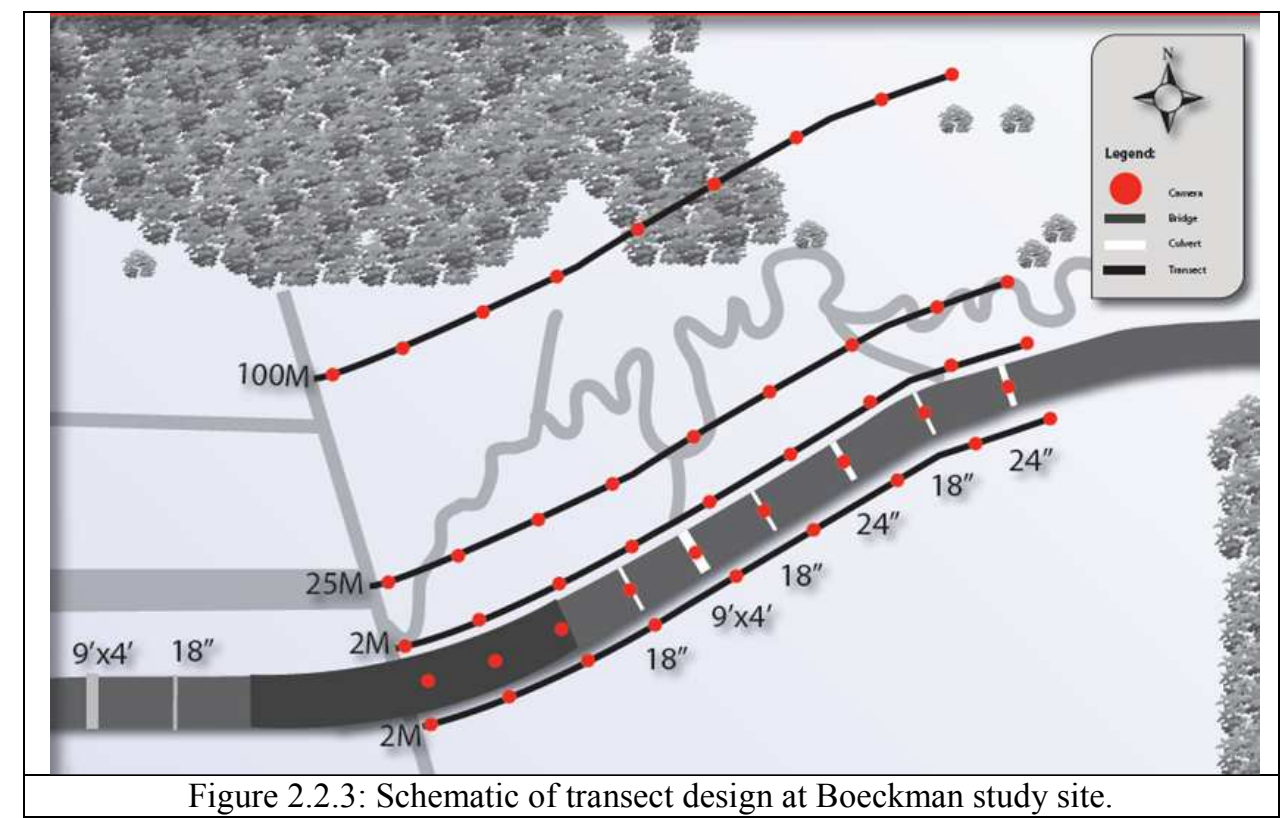

\subsubsection{Small Mammal Tag and Release}

Detection of small animal movement was limited with camera monitoring in the surrounding habitat because the angle and proximity to the ground necessary for the cameras to capture small animals would severely limit the range and ability to detect large and medium animal movements. In order to compensate for this shortcoming in camera data on small organisms, we also conducted tag-and-release studies targeted to small mammals. Trapping methods included pit traps (Figure 2.2.4) and Sherman traps (3"x 3.5" 9 9" folding aluminum). One of each type of trap was deployed per station for the $100 \mathrm{M}$ North, $25 \mathrm{M}$ North, $2 \mathrm{M}$ North and $2 \mathrm{M}$ South transects, for a total of 72 traps. Traps were deployed for three consecutive nights per month during late summer 2009 (31July-2 August, 25-27 August, and 21-23September). Traps were baited and opened at dusk, checked at dawn during trapping sessions, and then closed for the day. Voles and mice were tagged using metal ear bands (Figure 2.2.5) with unique identifying numbers, while shrews were released due to their lack of pinnae, which are required for placement of ear tags. 


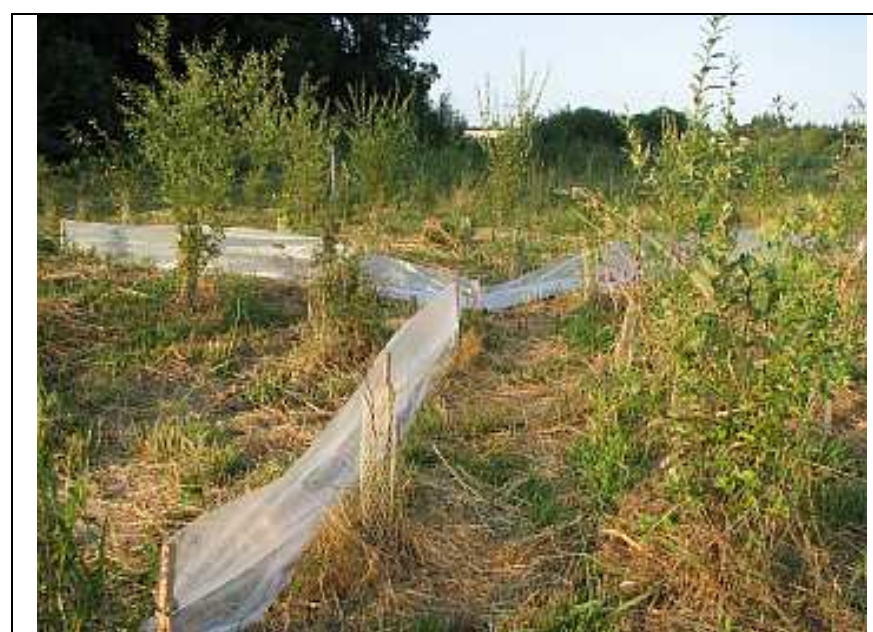

Figure 2.2.4: 100M North Station 1 pit trap array. One bucket is located in the center of the array of plastic sheeting.

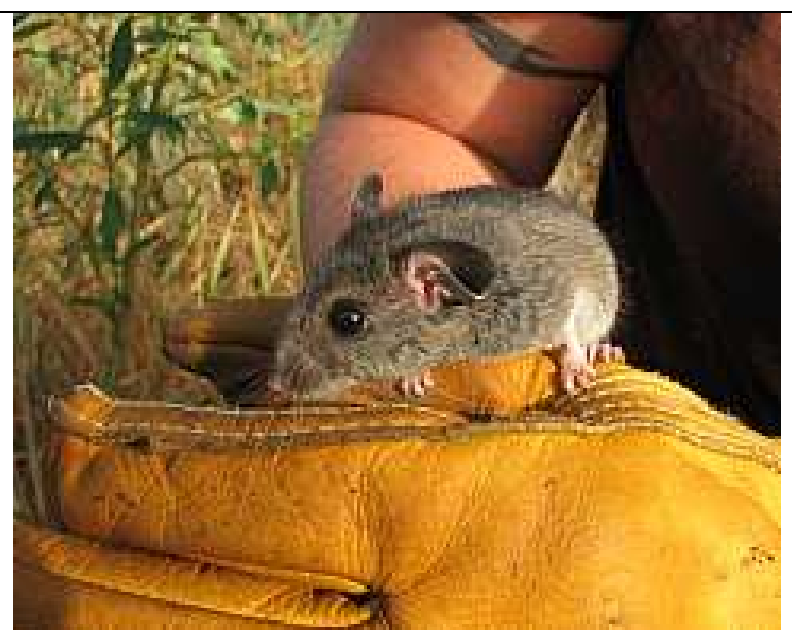

Figure 2.2.5: Deer mouse about to be released after capture and tagging during mark recapture study.

\subsubsection{Over-road Crossings}

Camera data collected in passage structures were compared to camera monitoring at the end of the exclusionary fencing (Figure 2.2.6). The direction animals were traveling was noted in order to best determine if the animal was about to, or had just, crossed the road surface.

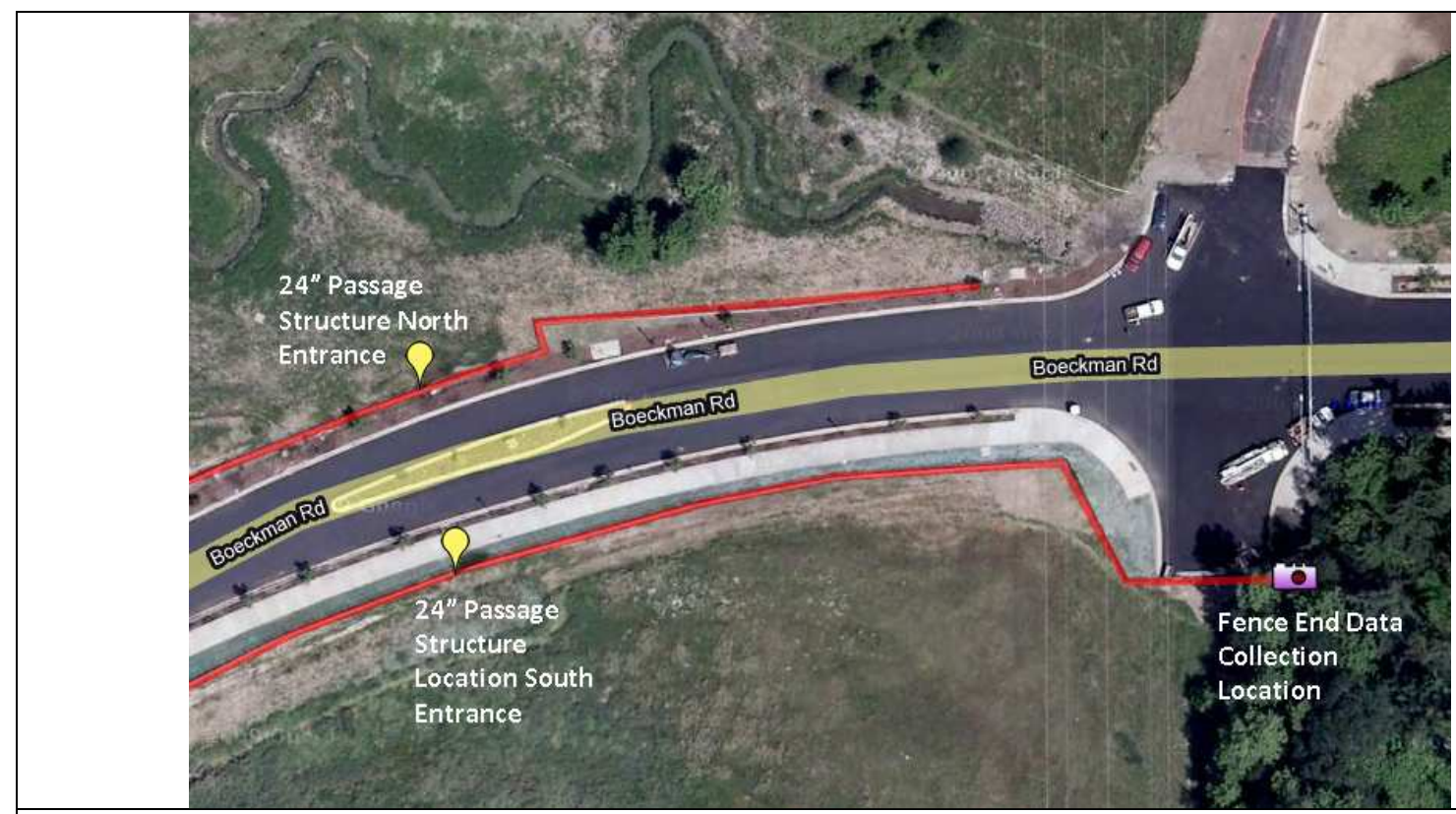

Figure 2.2.6: Fence end monitoring location in relation to fence end (red lines) and nearest passage (24-inchround concrete culvert).

\subsubsection{Artificial Light}

This study tested the hypotheses that artificial light will disrupt and/or alter use by nocturnal or crepuscular species. From May to June 2009, prior data was gathered by monitoring sections 2 and 3 of the bridge passage area for tracks using sand strips as well as cameras. The study team 
then fitted section 3 with artificial lighting and further monitored tracks and camera data in both locations. Testing of these hypotheses will resume in spring 2010 when animal activity increases and water levels subside.

\subsubsection{Vegetation}

In order to test that native browse plants within 10 feet of the passageway entrance will increase usage compared to plants further away or different types of plants, vegetation surveys were conducted by HDR, a consulting firm hired by the City of Wilsonville, in collaboration with this project. The vegetation data from these surveys will be correlated to passage use by animals; however, at this time these data are still being compiled and will be provided as a future appendix to this report.

\subsection{DATA ANALYSIS}

The study team compared passage use to expected use based on local movement in habitats to identify whether passages were used less than the surrounding habitat and, if so, the pattern and likely explanation for any decreased use (avoiding the road, not finding the passage entrance, or avoiding the passage entrance). Camera analysis and tag-and-release studies were pooled by transect to determine patterns in animal movements in relationship to the road. The $2 \mathrm{M}$ South transect was omitted from analyses, however, due to issues with topography and ability of camera locations to detect wildlife movement along this transect. Hence, analyses are based on five datapoints of pooled data per transect for just four transects. These data were analyzed with a Generalized Linear Model with a Poisson distribution and a log link function, using date as a blocking factor $(n=5)$; transect (using the road through the 100M North transect) and station nested within transect as independent factors; and the number of photos of mammals as the dependent factor. The study team tested the null hypothesis that activity of medium and large mammals in the surrounding area (along transects), then large mammals only, did not differ from activity through passages.

\subsection{STUDENT AND VOLUNTEER INVOLVEMENT}

During the course of this study there have been multiple opportunities for student and community involvement (Figure 2.4.1). Students at Portland State University have participated through various classes as well as through work-study opportunities. Students from the Environmental Science course Road Ecology added a comparative aspect to this study. They were able to assess multiple roads, including the Boeckman extension, for evidence of passage (if a structure is in place) and the need for passage structure through roadkill assessments. Also, students from multiple disciplines had the option of taking a Capstone course (Wildflife Movement Near Roads) that examined track pads and roadkill rates at the Boeckman site. Workstudy students and student volunteers provided vital assistance in both data collection and monitoring of the site, and in return gained valuable experience that may assist them in determining future academic directions. Community involvement opportunities included the 
grand opening event at Boeckman Road and interactions with the Center for Research in Environmental Science and Technologies (CREST). Community volunteers also provided opportunistic data on wildlife observations along or near the Boeckman Road site. Through the CREST program, in January 2010 students from West Lynn High started a tracking study at the Boeckman extension to assess seasonal shifts in animal movements.

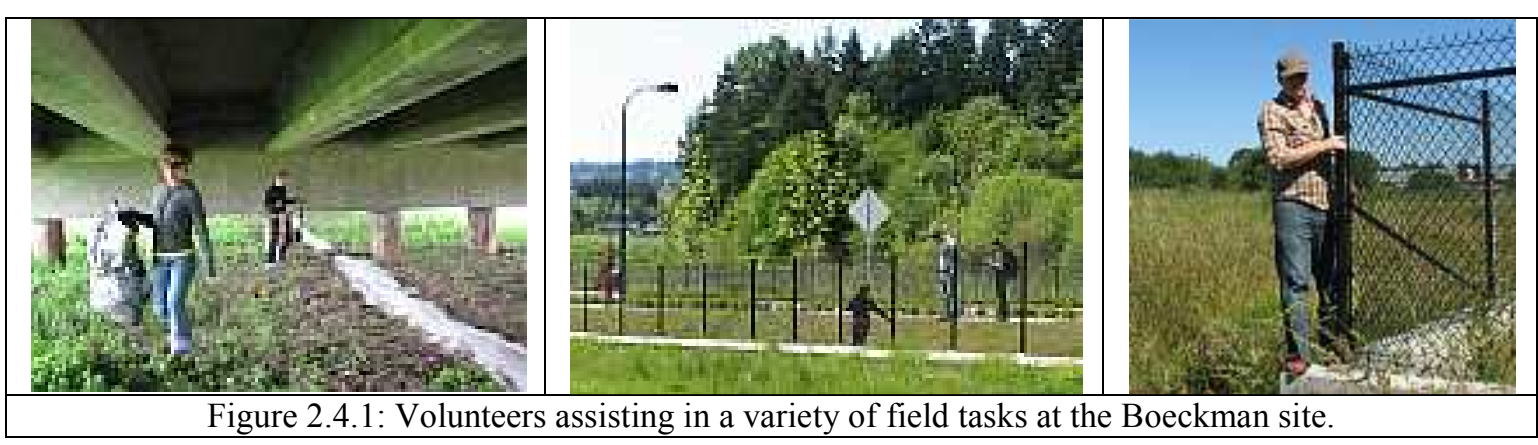




\subsection{RESULTS}

\subsection{USE OF AND COMPARISON OF PASSAGE STRUCTURES}

A total of 26 species were detected in this study: 73\% (19) of these species were found to be using passage structures; $15 \%$ (four) of the identified species were detected on transects but not in passages; and $11.5 \%$ (three) were detected in locations other than transects or passage structures (Table 3.1). Deer were the most common animal found at the site (Table 3.1).

The bridge spans over land were, by far, the most commonly used passage options, accounting for 18 of the 19 species found to use the passages, and for $85 \%$ of the total passage detections (sand-track and camera; Table 3.1, Figures 3.1.1, 3.1.2, 3.1.4). The camera-only data also identified the bridge as the most commonly used structure (Figure 3.1.3). The 18-inch round culverts had a similar amount and diversity of usage as the 24 -inch round culvert, with both trailing significantly behind the bridge and with, at most, one-fourth of the detections and twothirds of the species. The 9-foot-by-4-foot box culverts showed low passage use from both datasets. Some passages had standing water even in the dry season and some had blocked access (Table 3.2). Examining the total cost of each passage structure divided by their number of crossings in a four-month period revealed that the 9-by-4 culverts were by far the most expensive for the connectivity they provided (Figure 3.1.5). The bridge crossings were about 2.5 times more expensive than the small, round culverts, but they provided passage to many more species.

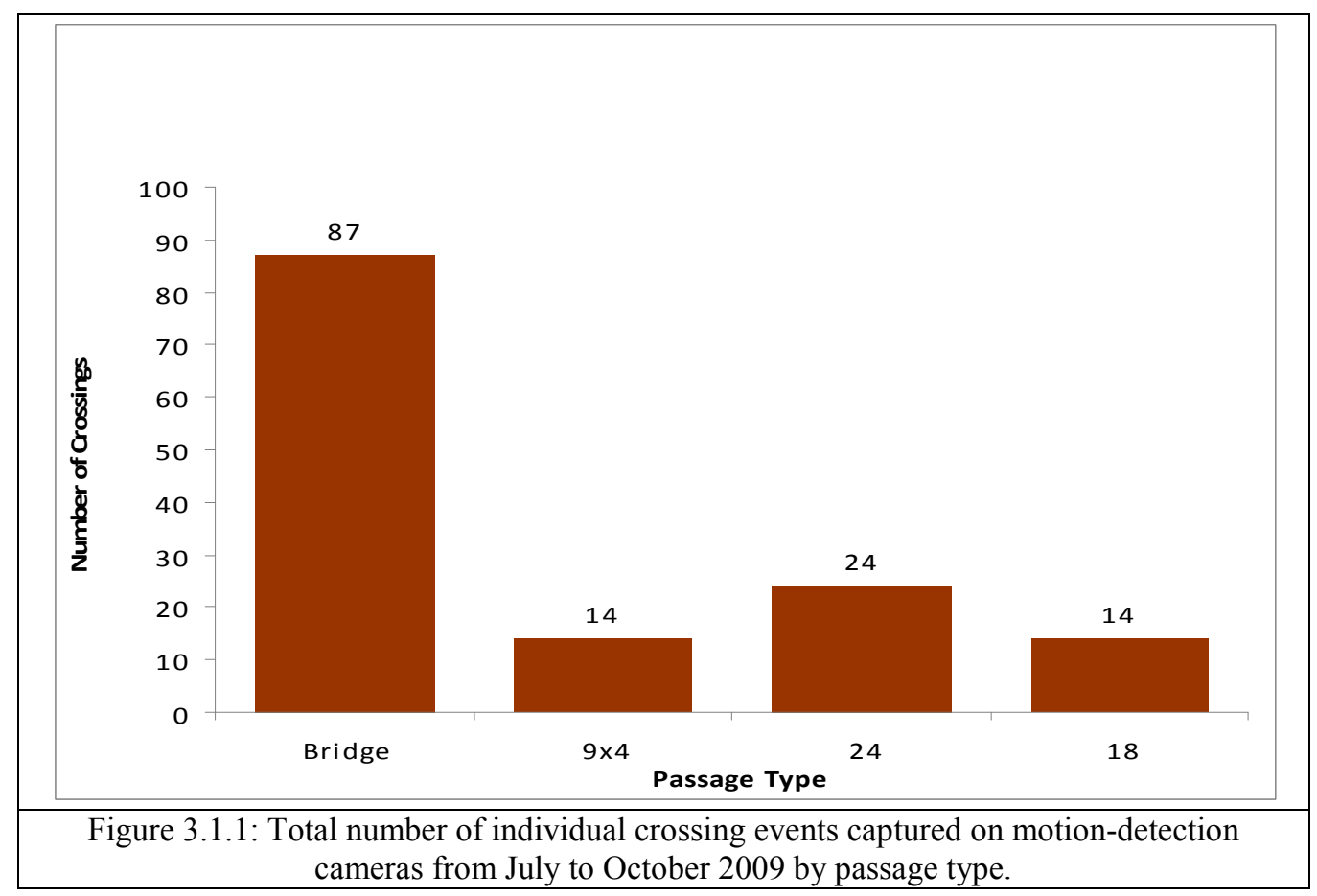



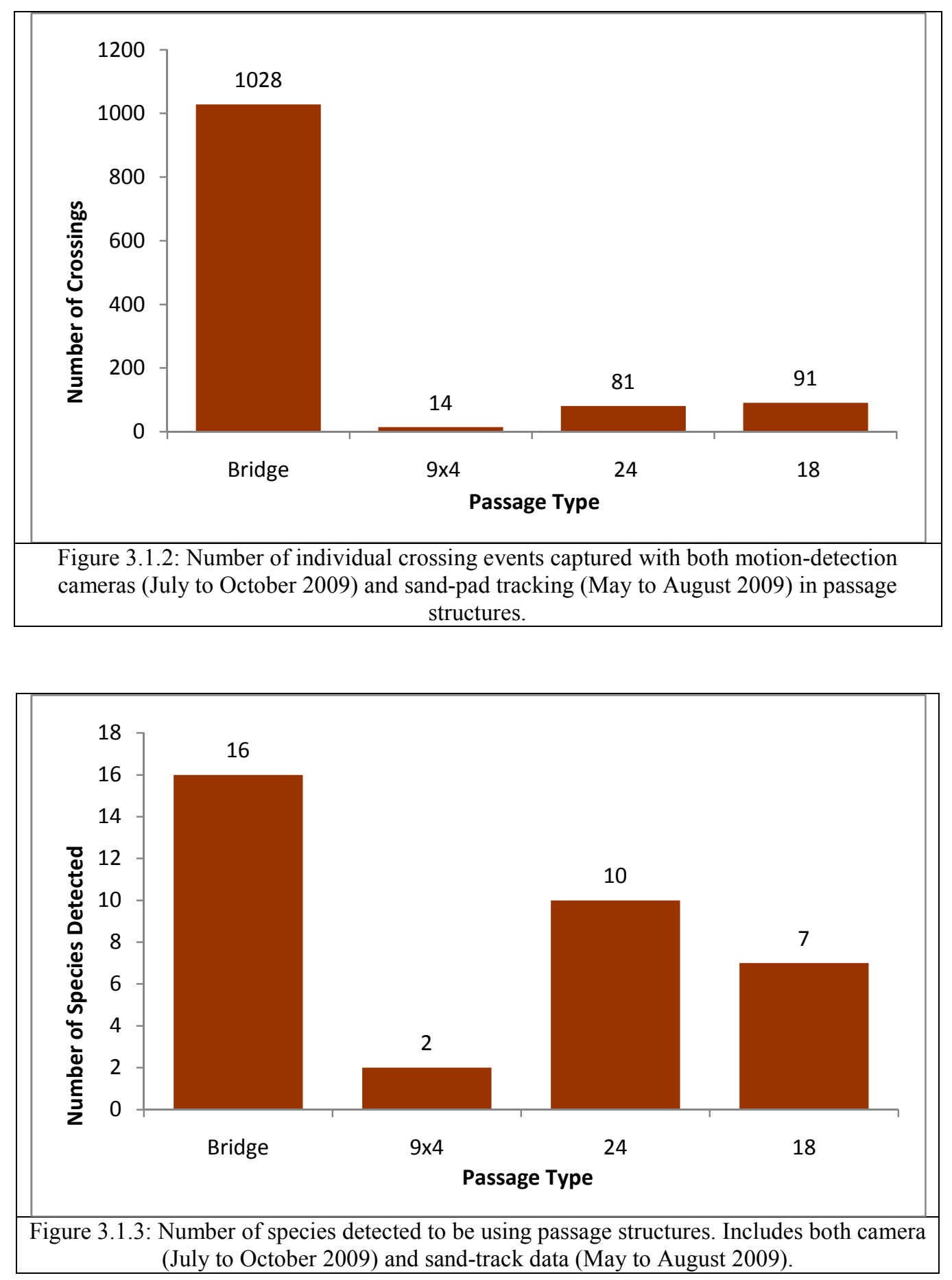


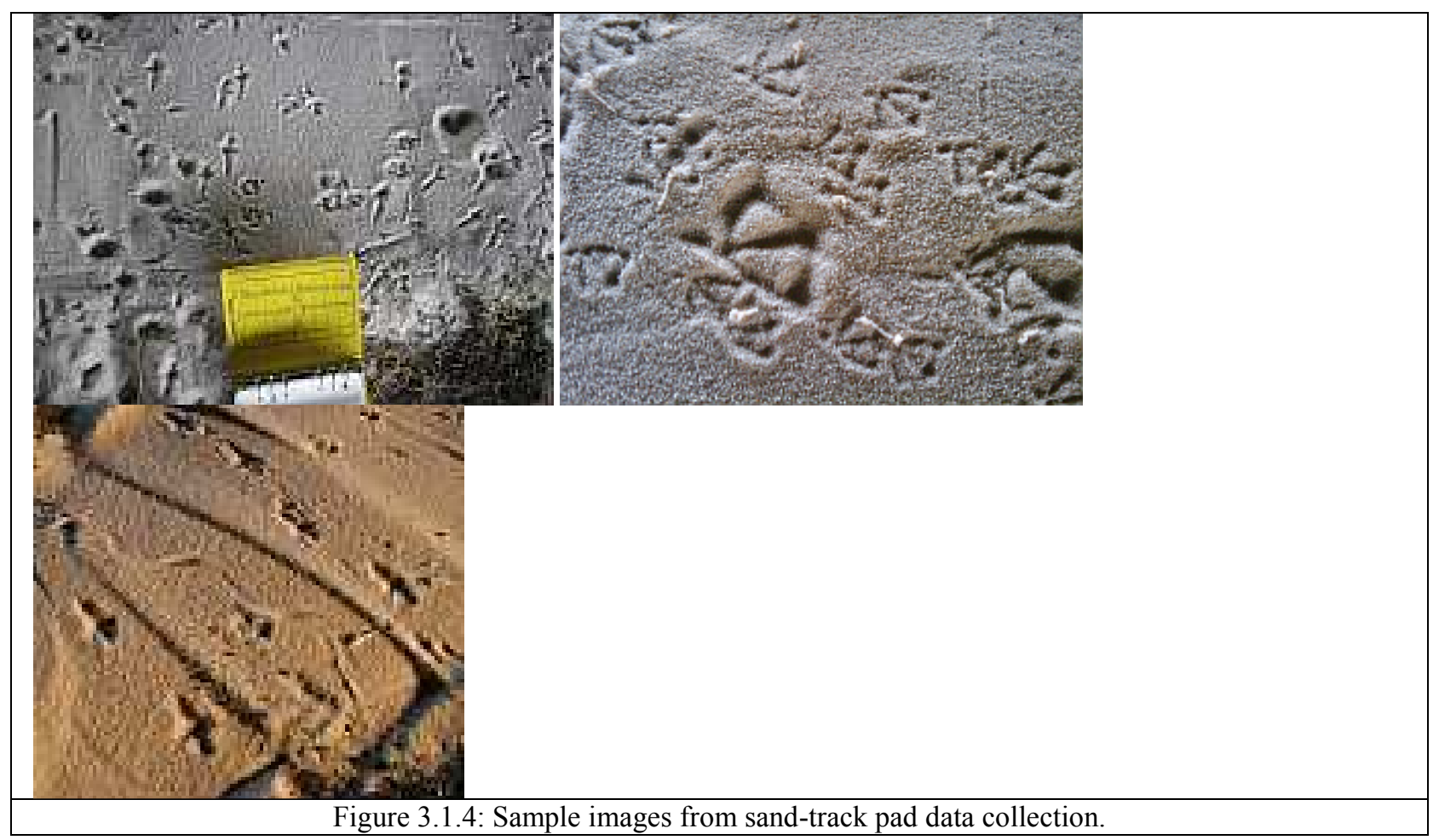

Table 3.1: Species detected through motion-detection camera and sand pad tracking using passage structures. Species names are listed under passage structure type and are followed by the number of observations from camera data (July to October 2009) and sand-track data for the bridge (May to June 2009; not needed for the culverts).

\begin{tabular}{|c|c|c|c|c|c|c|c|c|c|}
\hline $\begin{array}{r}\text { Common } \\
\text { Name } \\
\end{array}$ & $\begin{array}{r}\text { Species } \\
\text { Latin binomial } \\
\end{array}$ & $\begin{array}{l}\text { Bridge } \\
\text { Passages } \\
(1,2 \text { \& 3) } \\
\text { Camera } \\
\end{array}$ & $\begin{array}{l}\text { Sand } \\
\text { Tracks } \\
\text { (Bridge } \\
2 \text { \& 3) } \\
\end{array}$ & $\begin{array}{l}\text { 9x4 } \\
\text { Box } \\
\text { Camera } \\
\end{array}$ & $\begin{array}{l}24 \% \\
\text { Round } \\
\text { Camera }\end{array}$ & $\begin{array}{l}\text { 18” } \\
\text { Round } \\
\text { Camera }\end{array}$ & $\begin{array}{l}\text { Off } \\
\text { Road- } \\
\text { Transect } \\
\text { Camera } \\
\end{array}$ & $\begin{array}{l}\text { Total in } \\
\text { passages }\end{array}$ & $\begin{array}{l}\text { Total } \\
\text { w/o } \\
\text { Sand }\end{array}$ \\
\hline Newt & $\begin{array}{r}\text { likely Taricha } \\
\text { granulosa }\end{array}$ & & 4 & & & & & 4 & \\
\hline Tree frog & Hyla regilla & & 33 & & & & & 33 & \\
\hline Bullfrog & Rana catesbeiana & & 12 & & 2 & 5 & & 19 & 7 \\
\hline & Total Amphibians & & 49 & & 2 & 5 & & 56 & 7 \\
\hline Garter snake & Thamnophis spp. & & 20 & & & & & 20 & \\
\hline & Total Reptiles & & 20 & & & & & 20 & \\
\hline $\begin{array}{r}\text { Great Blue } \\
\text { Heron }\end{array}$ & Ardea herodias & 1 & 4 & & & & & 5 & 1 \\
\hline Mallard & Anas platyrhynchos & & 10 & 9 & & & & 19 & 9 \\
\hline $\begin{array}{r}\text { American } \\
\text { Bittern } \\
\end{array}$ & $\begin{array}{r}\text { Botaurus } \\
\text { lentiginosus } \\
\end{array}$ & & & & & & $25 \mathrm{M} \mathrm{N}$ & & \\
\hline Pheasant & Phasianus colchicus & 2 & 15 & & & & & 17 & 2 \\
\hline & Total Birds & 3 & 29 & 9 & & & & 41 & 12 \\
\hline $\begin{array}{r}\text { Deer } \\
\text { Mouse }\end{array}$ & $\begin{array}{l}\text { Peromyscus } \\
\text { maniculatus }\end{array}$ & & 277 & & 36 & 70 & & 383 & 106 \\
\hline Rat & Rattus norvegicus & & & & 2 & & & 2 & 2 \\
\hline Vole & Microtus townsendii & & 146 & & 14 & 3 & & 163 & 17 \\
\hline Shrew & Sorex vagrans & & 3 & & 2 & & & 5 & 2 \\
\hline
\end{tabular}




\begin{tabular}{|c|c|c|c|c|c|c|c|c|c|}
\hline Opossum & $\begin{array}{c}\text { Didelphis } \\
\text { virginiana }\end{array}$ & & 14 & & 2 & 1 & & 17 & 3 \\
\hline Rabbit & $\begin{array}{l}\text { Sylvilagus } \\
\text { floridanus }\end{array}$ & & & & & & $100 \mathrm{M} \mathrm{N}$ & & \\
\hline Beaver & Castor canadensis & & & & & & $25 \mathrm{M} \mathrm{N}$ & & \\
\hline Nutria & Myocastor coypus & & & & & & $25 \mathrm{M} \mathrm{N}$ & 1 & \\
\hline Coyote & Canis latrans & & 15 & & & & & 15 & \\
\hline Chipmunk & Tamias townsendii & & & & & & $\begin{array}{l}\text { Fence } \\
\text { End }\end{array}$ & & \\
\hline $\begin{array}{r}\text { Fox } \\
\text { Squirrel } \\
\end{array}$ & Sciurus niger & & & & & & $\begin{array}{l}\text { off } \\
\text { transect }\end{array}$ & & \\
\hline Dog & $\begin{array}{r}\text { Canis lupus } \\
\text { familiaris }\end{array}$ & 2 & & & & & & 2 & 2 \\
\hline Raccoon & Procyon lotor & 11 & 36 & 5 & 18 & 11 & & 81 & 45 \\
\hline $\begin{array}{r}\text { Short- } \\
\text { Tailed } \\
\text { Weasel }\end{array}$ & Mustela erminea & & 3 & & & & & 3 & \\
\hline Skunk & Mephitis mephitis & 1 & 25 & & 1 & 1 & & 28 & 3 \\
\hline House cat & Felis catus & 19 & 62 & & 3 & 1 & & 85 & 23 \\
\hline Bobcat & Lynx rufus & & & & & & $\begin{array}{l}\text { off } \\
\text { transect }\end{array}$ & & \\
\hline Deer & $\begin{array}{r}\text { Odocoileus } \\
\text { hemionus } \\
\text { columbianus }\end{array}$ & 72 & 273 & & & & & 345 & 72 \\
\hline & Total Mammals & 105 & 855 & 5 & 78 & 87 & & 1130 & 275 \\
\hline Human & Homo sapiens & 2 & 1 & & & & & 3 & 2 \\
\hline & Grand Total & 110 & 953 & 14 & 80 & 92 & & 1249 & 296 \\
\hline
\end{tabular}

Table 3.2: Passage structure conditions as noted on August 31, 2009.

\begin{tabular}{l|l|l}
\hline & $\begin{array}{l}\text { \% Standing } \\
\text { Water }\end{array}$ & Notes \\
\hline 24 Inch (east-most) & 0 & Muddy but no standing water \\
\hline 18 Inch & 0 & Dry, but perched ( 0.3m off ground) on north side \\
\hline 24 Inch & 0 & Dry, clear view through \\
\hline 18 Inch & 35 & North side dry, south side wet \& muddy \\
\hline $9 x 4$ & 80 & Only dry in small patches - no dry path all the way through \\
\hline 18 Inch & 50 & Blocked by soil, north side has large pool at entrance \\
\hline Bridge & 0 & Dry other than wetted perimeter of ditch \\
\hline
\end{tabular}




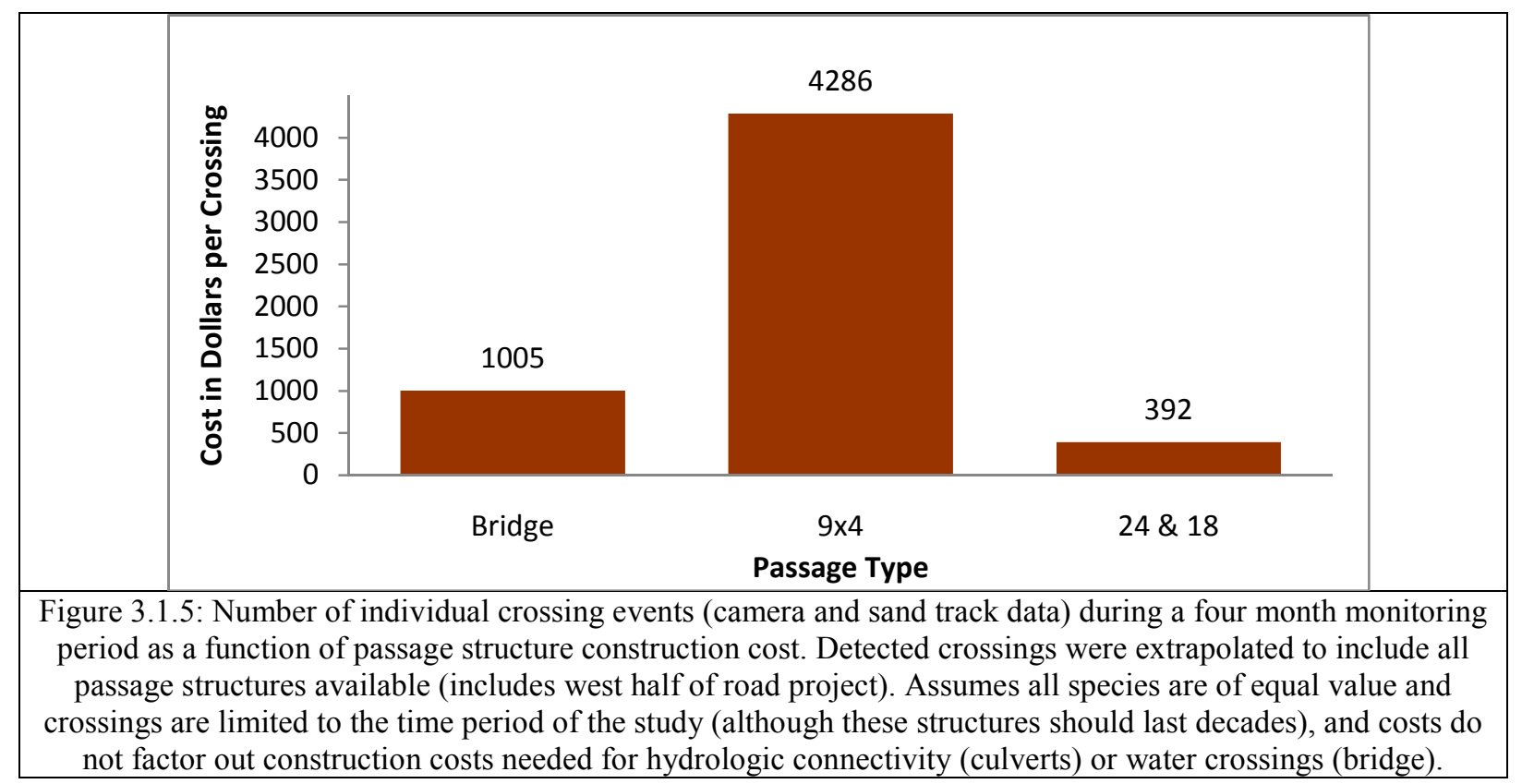

\subsection{COMPARISON OF PASSAGE STRUCTURE USE TO SURROUNDING HABITATS}

The habitat transects did not differ significantly from the road transect or each other with regard to the number of large and medium mammals detected (Table 3.3, Figure 3.2.1; Generalized linear model: overall model Likelihood ratio $\chi^{2}=375.55, \mathrm{df}=39, \mathrm{P}=<0.001$; transect $\chi^{2}=1.99$, $\mathrm{df}=3, \mathrm{P}=0.575$; station [transect] $\chi^{2}=242.66, \mathrm{df}=32, \mathrm{P}<0.001 ;$ Block $\chi^{2}=54.84, \mathrm{df}=4, \mathrm{P}<$ $0.001)$. Deer were most commonly detected at the $100 \mathrm{M}$ transect $(\mathrm{n}=124$ observations) and least commonly detected at the under-road crossings $(n=72$; Table 3.3, Figure 3.2.2).

Examination of the deer alone provided a contrast to the combined analysis: Deer were detected significantly less often at the road than along the transects in the surrounding habitat (Figure 3.2.3; Generalized linear model: overall model Likelihood ratio $\chi^{2}=433.30, \mathrm{df}=39, \mathrm{P}=<0.001$; transect $\chi^{2}=14.95, \mathrm{df}=3, \mathrm{P}=0.002$; station [transect] $\chi^{2}=156.50, \mathrm{df}=25, \mathrm{P}<0.001$; Block $\chi^{2}=$ $45.17, \mathrm{df}=4, \mathrm{P}<0.001)$. The second and fourth most commonly detected species, raccoons and domestic cats, appear to be detected more often near the road (Fig 3.2.3). The least commonly detected species have much higher variation in detected movement by transect: Their movement peaked at the $25 \mathrm{M}$ transect, which frequently intersects with meandering waterways (Figure 2.2.2.1), and the road (Figure 3.2.4). Deer shifted their routes over time once the vegetation planted at the site had developed seasonal foliage and grown (Figure 3.2.5).

In pit and Sherman traps, 16 of the 48 small mammals that were captured and tagged were recaught, but only four of these moved from one transect to another. Two moved away from the road, one toward the road, and one toward and under the road to the far transect. Almost all of the marked animals were deer mice (43). Voles comprised the remainder of the marked animals (five), and none of these were recaptured. 


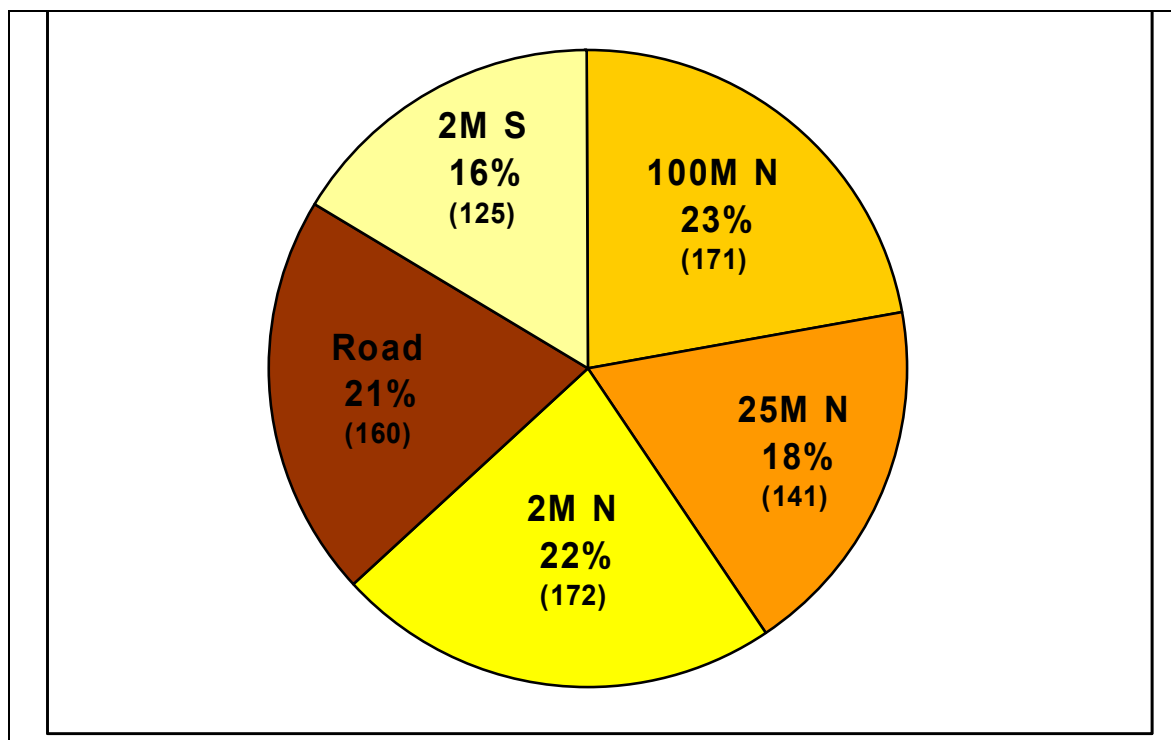

Figure 3.2.1: Percent of animal crossings detected by cameras per transect (excludes small mammals, reptiles, and amphibians due to the low detection probability off-road).

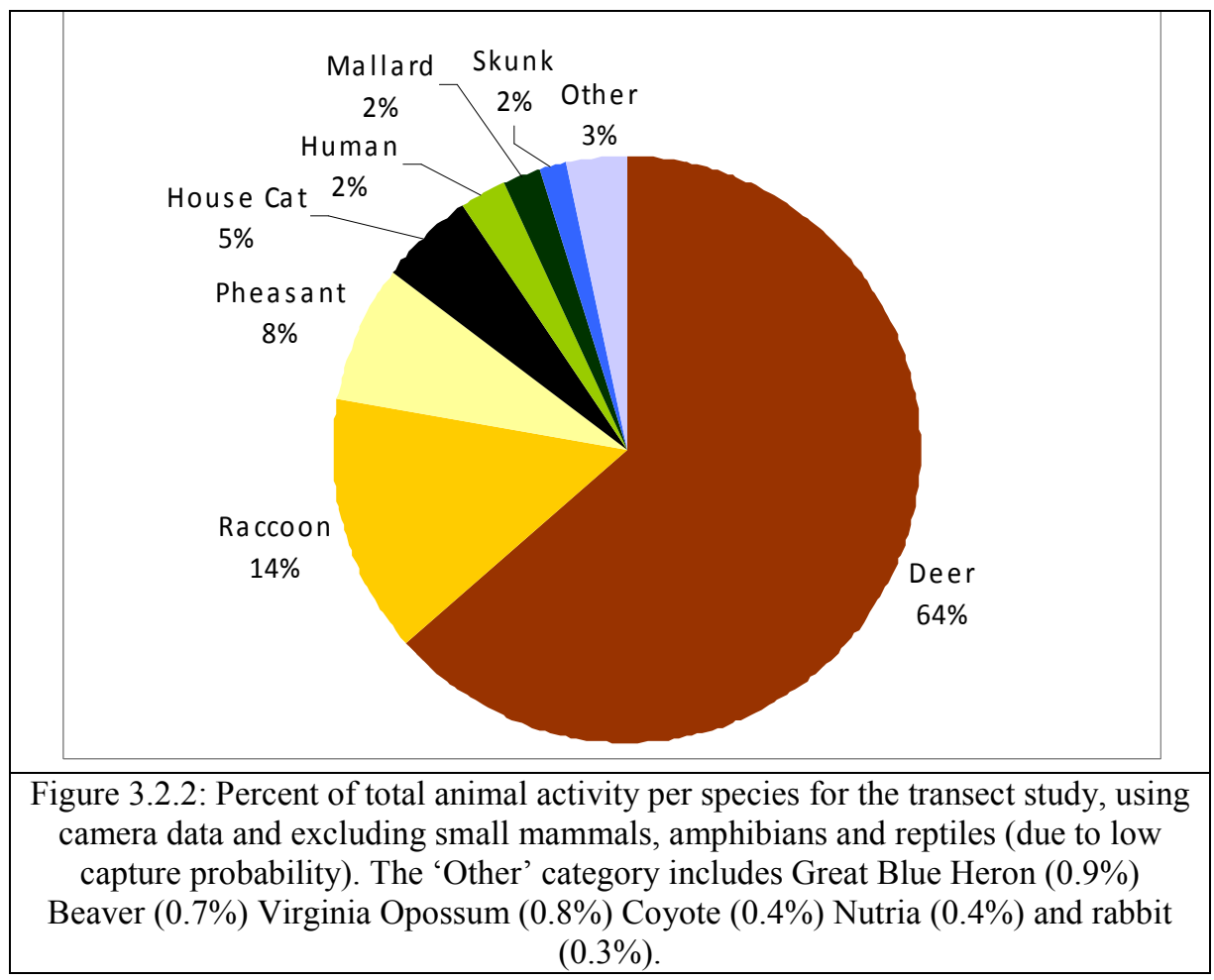




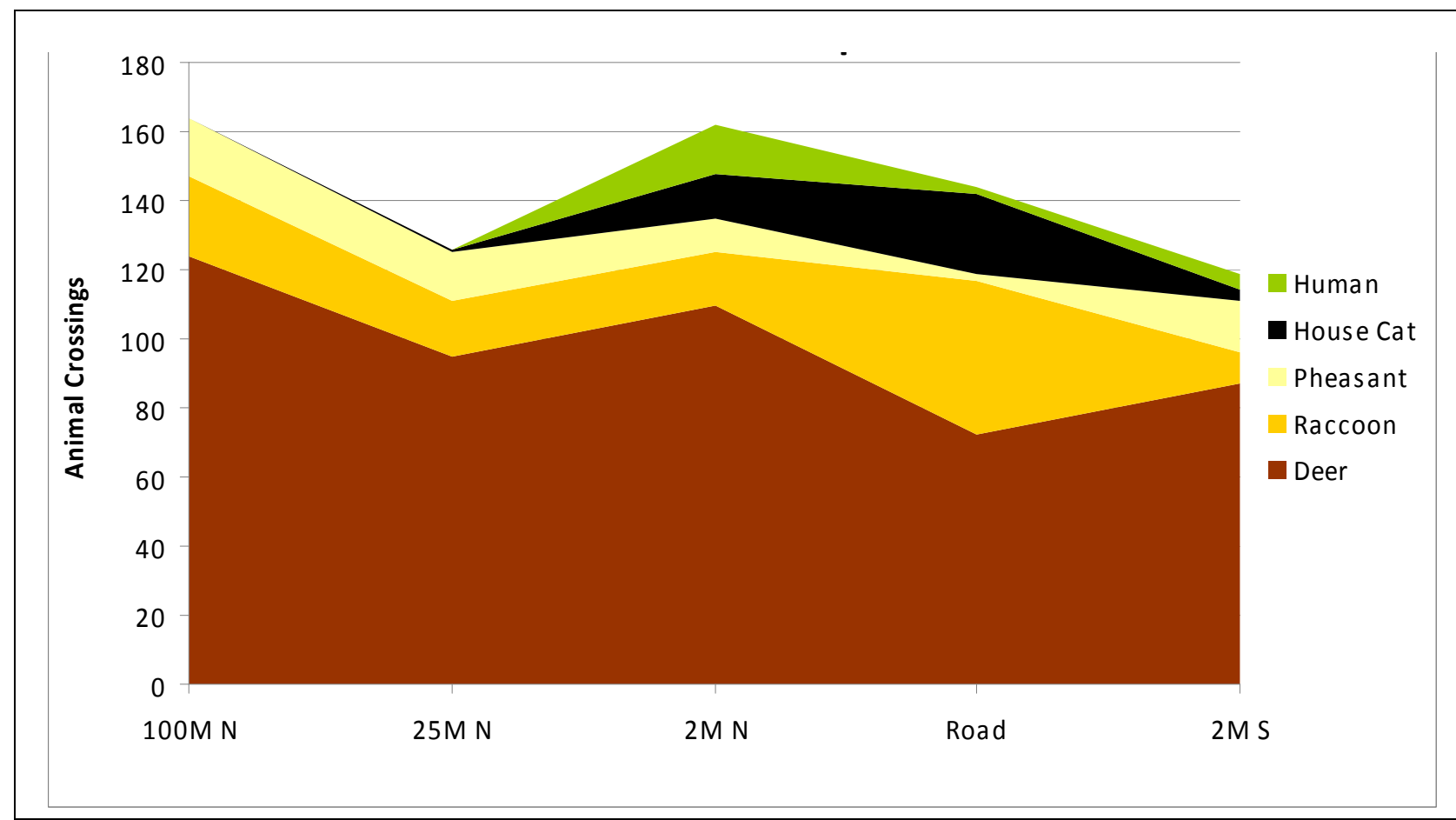

Figure 3.2.3: Total animal activity by transect for the most commonly detected species (camera data): human, house cat, pheasant, raccoon, and deer.

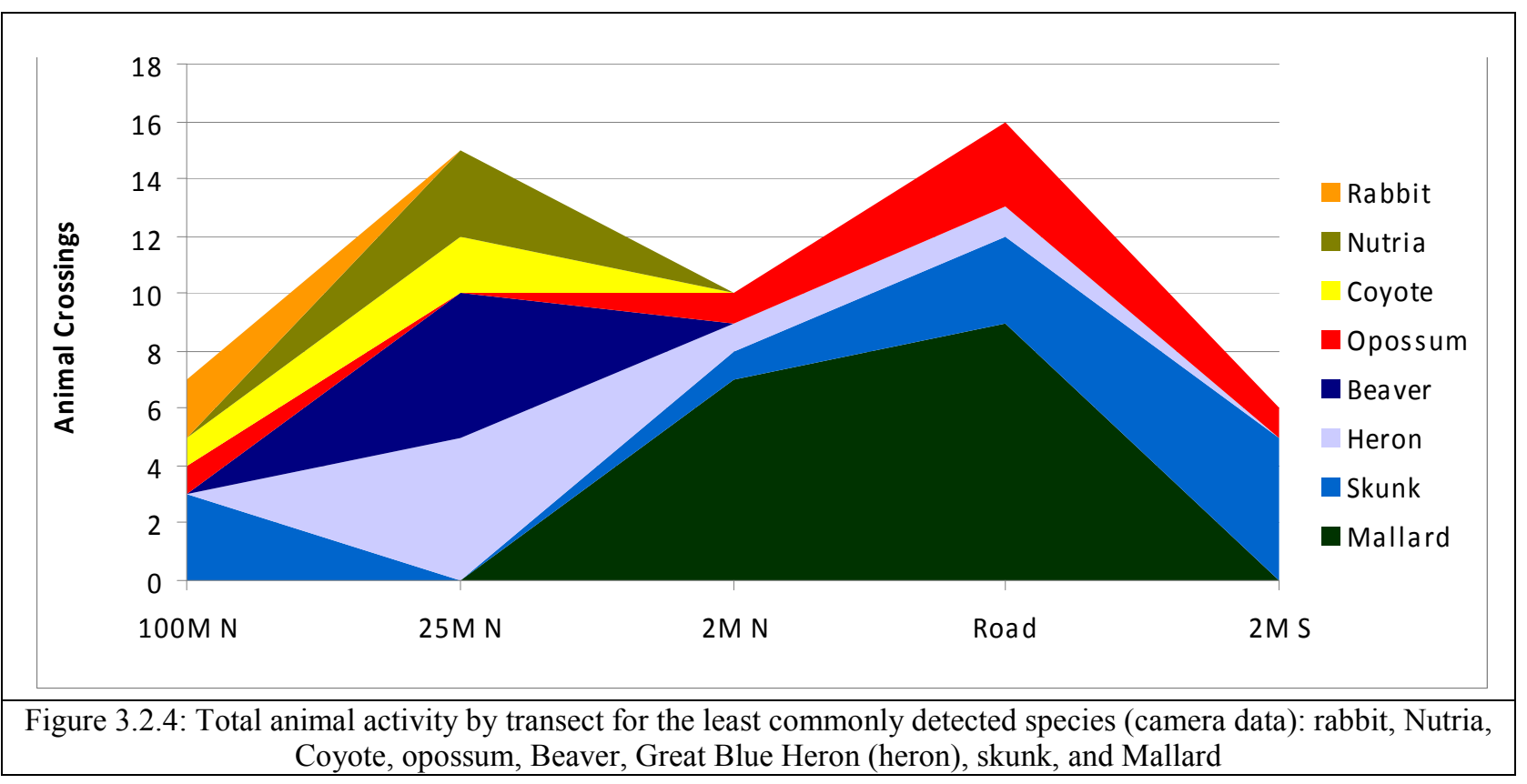




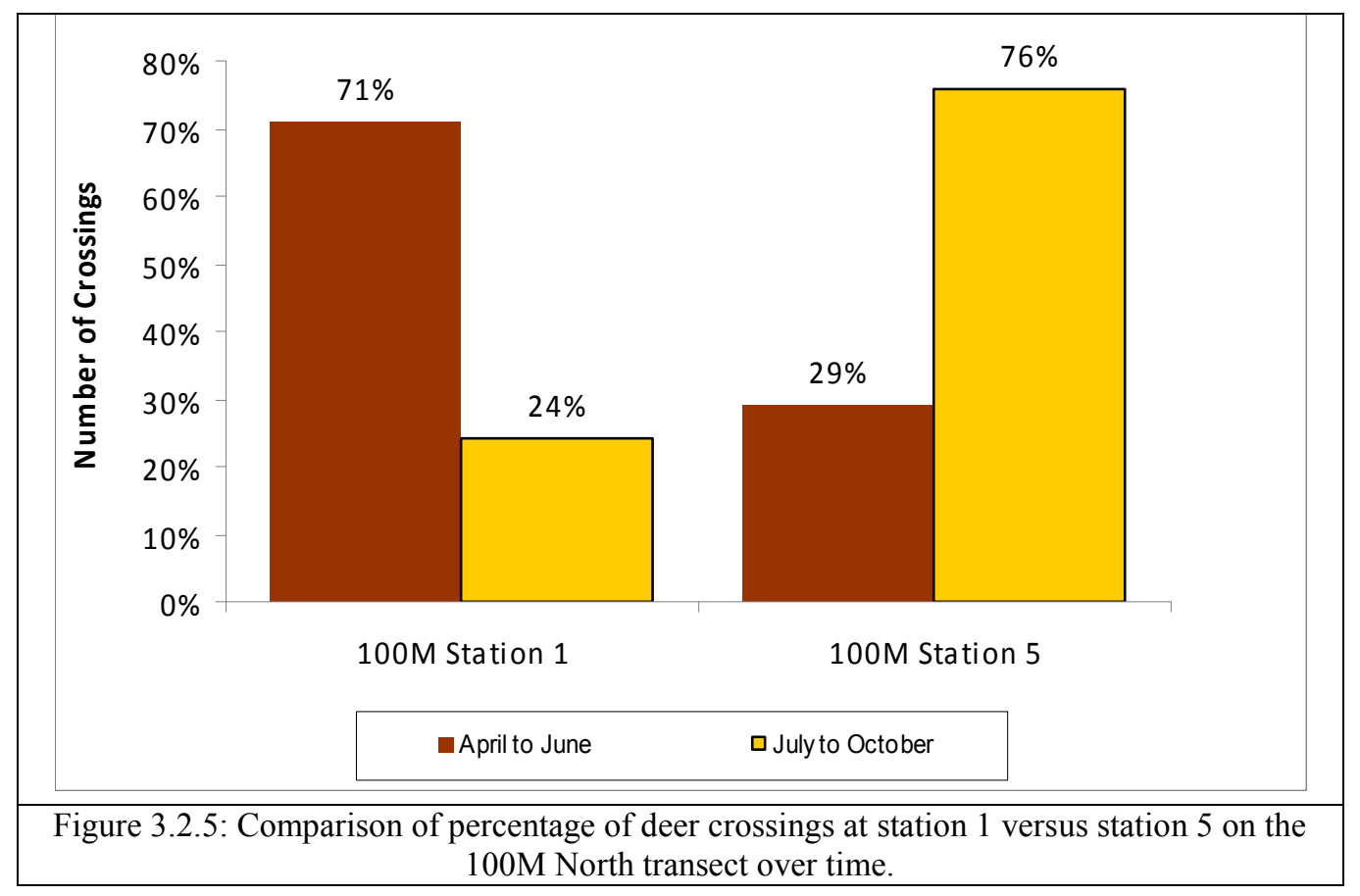

\begin{tabular}{|c|c|c|c|c|c|c|c|c|}
\hline Species & Latin binomial & Vertebrate Group & $\begin{array}{l}100 M \\
N \\
\end{array}$ & $\begin{array}{l}25 \mathrm{M} \\
\mathrm{N} \\
\end{array}$ & $\begin{array}{l}2 \mathrm{M} \\
\mathbf{N} \\
\end{array}$ & Road & $\begin{array}{l}2 \mathrm{M} \\
\mathrm{S} \\
\end{array}$ & Total \\
\hline Bullfrog & Rana catesbeiana & Amphibian & & & & 7 & & 7 \\
\hline Great Blue Heron & Ardea herodias & Bird & & 5 & 1 & 1 & & 7 \\
\hline Mallard & Anas platyrhynchos & Bird & & & 7 & 9 & & 16 \\
\hline Pheasant & Phasianus colchicus & Bird & 17 & 14 & 10 & 2 & 15 & 58 \\
\hline Deer Mouse & Peromyscus maniculatus & Small Mammal & 6 & 1 & & 106 & & 113 \\
\hline Rat & Rattus norvegicus & Small Mammal & & & & 2 & & 2 \\
\hline Vole & Microtus townsendii & Small Mammal & & & & 17 & & 17 \\
\hline Shrew & Sorex vagrans & Small Mammal & & & & 2 & & 2 \\
\hline Opossum & Didelphis virginiana & Medium Mammal & 1 & & 1 & 3 & 1 & 6 \\
\hline Rabbit & Sylvilagus floridanus & Medium Mammal & 2 & & & & & 2 \\
\hline Beaver & Castor canadensis & Medium Mammal & & 5 & & & & 5 \\
\hline Nutria & Myocastor coypus & Medium Mammal & & 3 & & & & 3 \\
\hline Coyote & Canis latrans & Medium Mammal & 1 & 2 & & & & 3 \\
\hline Raccoon & Procyon lotor & Medium Mammal & 23 & 16 & 15 & 45 & 9 & 108 \\
\hline Skunk & Mephitis mephitis & Medium Mammal & 3 & & 1 & 3 & 5 & 12 \\
\hline House cat & Felis catus & Medium Mammal & & 1 & 13 & 23 & 3 & 40 \\
\hline Deer & $\begin{array}{l}\text { Odocoileus hemionus } \\
\text { columbianus }\end{array}$ & Large Mammal & 124 & 95 & 110 & 72 & 87 & 488 \\
\hline \multirow[t]{3}{*}{ Human } & Homo sapiens & Human & & & 14 & 2 & 3 & 19 \\
\hline & & Total & 177 & 142 & 172 & 295 & 123 & 909 \\
\hline & & Total Amphibian & 0 & 0 & 0 & 7 & 0 & 7 \\
\hline
\end{tabular}




\begin{tabular}{r|r|l|r|r|r|r|r|r}
\hline & & Total Reptile & 0 & 0 & 0 & 1 & 0 & 1 \\
\hline & & Total Bird & 17 & 19 & 18 & 12 & 15 & 81 \\
\hline & & $\begin{array}{l}\text { Total Small } \\
\text { Mammal }\end{array}$ & 6 & 1 & 0 & 127 & 0 & 134 \\
\hline & & $\begin{array}{l}\text { Total Medium } \\
\text { Mammal }\end{array}$ & 30 & 27 & 30 & 74 & 18 & 179 \\
\hline & & $\begin{array}{l}\text { Total Large } \\
\text { Mammal }\end{array}$ & 124 & 95 & 110 & 72 & 87 & 488 \\
\hline & & Total Human & 0 & 0 & 14 & 2 & 3 & 19 \\
\hline & & $\begin{array}{l}\text { Total Excluding } \\
\text { Humans, Small } \\
\text { Mammals, Reptiles } \\
\text { \& Amphibians }\end{array}$ & 171 & 141 & 158 & 158 & 120 & 748 \\
\hline
\end{tabular}

Note: Due to their proximity to the ground, the cameras in the culverts had a much higher likelihood of detection of small animals (e.g., mice) than ones elsewhere.

\subsection{COMPARISON OF PASSAGE STRUCTURE USE TO OVER-ROAD CROSSINGS}

For medium and large mammals and birds, the species detected with cameras at the passage structures or circumventing fencing, $19 \%$ (33) of the 139 individuals were found potentially crossing on the road surface (Figure 3.3.1). While there were other locations further east without fencing where animals could have chosen to cross, the location monitored captured animals following fencing to the end and crossing the road, rather than using passage structures. Nearly equal numbers of opossum and skunk were observed circumvented fencing as were detected using passages. The proportion of deer detected using over-road crossings (23\%) is of particular concern for driver safety (Table 3.4).

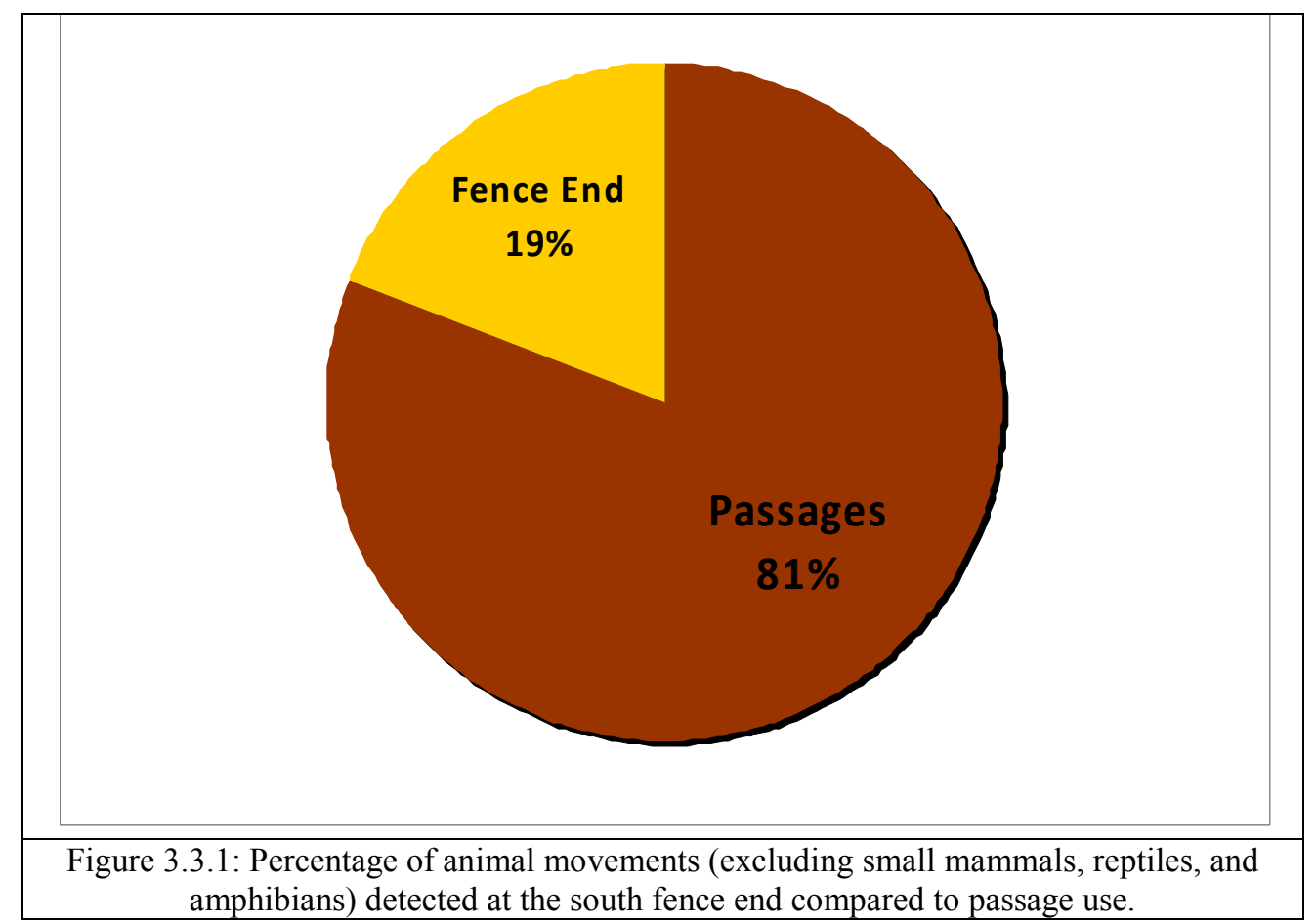


Table 3.4: Crossings through passage structures as compared to crossing over the road surface around prevention fencing (camera data only).

\begin{tabular}{l|l|l|r|r}
\hline Species & Latin binomial & $\begin{array}{l}\text { Vertebrate } \\
\text { Group }\end{array}$ & $\begin{array}{l}\text { Passage } \\
\text { Structures }\end{array}$ & \multicolumn{1}{l}{$\begin{array}{l}\text { Fence } \\
\text { End }\end{array}$} \\
\hline Great Blue Heron & Ardea herodias & Bird & 1 & \\
\hline Mallard & Anas platyrhynchos & Bird & 9 & \\
\hline Pheasant & Phasianus colchicus & Bird & 2 & 2 \\
\hline Opossum & Didelphis virginiana & Medium Mammal & 3 & 4 \\
\hline Raccoon & Procyon lotor & Medium Mammal & 45 & 4 \\
\hline Skunk & Mephitis mephitis & Medium Mammal & 3 & 2 \\
\hline House cat & Felis catus & Medium Mammal & 4 & 21 \\
\hline Deer & Odocoileus hemionus columbianus & Large Mammal & 72 & 33 \\
\hline & & Total & 139 & \\
\hline
\end{tabular}




\subsection{DISCUSSION}

This initial, short-term assessment suggests that, on the whole, the passage structures provided connectivity across the landscape. Nineteen of the 23 species detected with cameras within the study transects were seen in the passage structures. Moreover, $21 \%$ of the detections designed to compare passage structures to four habitat transects occurred in the passage structures. Because individuals were not followed -so an individual moving across the study site potentially could be detected at four transects and a passage structure- the null expectation would be passage structures, if the road did not serve as a block at all, would account for one-fifth $(20 \%)$ of the sightings. Although a camera at a passage structure would have higher capture probability of an animal walking across all transects than a station in the surrounding habitat if the cameras had a short range, the cameras were able to detect medium and large animals passing almost as far away as the neighboring stations. Therefore, detection probability should not be biased toward the road transect, especially for large mammals.

While overall connectivity was provided at the site, not all passage structures were equally effective. The bridge structure provided passage for the highest number of species (16) followed by the 24-inch and 18-inch culverts combined (11). Lastly, the 9-foot-by-4-foot culverts accounted for two species detected. This is due in part to the fact that some species, deer in particular, are not physically able to fit through the smaller culverts. However, reptiles (snakes), which could fit through smaller culverts, were never detected using structures other than the bridge. Rather than an issue with road avoidance, the study team believes this is due to the physical conditions within the smaller passages. Specifically, the reduced temperature within the 24-inch and 18-inch culverts could make them less preferred by reptiles and amphibians. The standing water in the 9-by-4 structure also likely accounts for the lack of use by most of the species at the site.

A potential method for assessing the usefulness of each type of passage is to use the number of crossings per cost of construction (Figure 3.1.5). This simple metric suggested the smallest passages (24-inch and 18-inch) provided the best value per crossing. This assessment, however, did not attempt to consider one species of greater value than another, so species such as voles were ranked equally with deer. Depending on the species in any given area, such as endangered or threatened animals or ones that cause damage to vehicles, the size of an animal may be of more or less concern in regards to maintaining habitat connectivity and/or preserving driver safety. Including a weighting for larger species would greatly increase the priority of an overland bridge extension. Similarly, including diversity of animals rather than just number of passages would strongly favor the bridge. Furthermore the total cost of the passage structures is not necessarily the true cost of providing animal passage, for the Boeckman project specifically a bridge structure would have been constructed regardless of the consideration for wildlife crossings due to the presence of a waterway, but likely would have been much smaller than the current bridge length. While this analysis simply considered the total cost of the structures and gave all animals equal weight a more accurate model would increase the value per crossing. 
This study was not able to examine the species-specific relative use of completely functioning passage structures for each passage type, however, because the 9-foot span-by-4-foot high culvert and some of the smaller ones were compromised by standing water or sediment. Therefore, some of the passage structures were functioning as planned and have been effectively serving to connect the habitat on either side of the road, but the others - the flooded and partially filled culverts - were not. The standing water in the 9-by-4 culvert limited the use of this passage to waterfowl and raccoons, species with no aversion to aquatic environments.. If the floor of this passage type were dry, at minimum to the point where a "trail" of dry ground would span the distance from the north to the south side of the road, the number of species willing and able to pass would likely increase. Proper placement, installation, and maintenance of such structures may have greatly facilitated passage by small and medium mammals. It also may have reduced the number of crossings by these animals across the road surface.

To maintain and enhance the functionality of passages, other than the bridge, the issues of standing water and potential for clogging will need to be periodically assessed and in the case of the 9-foot-by-4-foot culvert, corrected. The bridge does not require maintenance for issues of clogging or standing water due to its high clearance and ability to drain at a similar rate to surrounding habitat. The lack of these costly maintenance needs and high diversity of species use assist us in understanding and justifying the increased upfront cost associated with bridge passage. Similarly, in order to maintain the prevention structures, vegetation along the amphibian wall will need to be periodically mowed to prevent it from growing over and losing functionality.

The commonly detected large and medium mammals (Figure 3.2.3) overall appeared to have equal distribution across the landscape, and did not use passages less than would be expected based on their local movement in habitats. Therefore, overall, large and medium animals were not avoiding the road or the passage entrances and were finding the passage entrances. Some variation exists, however, at a species level. Examination of the deer alone showed that deer were not using the under-road passages as much as would be expected by their presence in the surrounding habitat, likely due to over-road crossings beyond the end of the main study transect (see discussion below). The study team did not have a large enough sample of the other animals to analyze them individually, but visual examination of the data suggest pheasants also may be moving more in areas further from the road while raccoons and cats traveled more near the road than farther from it (Figure 3.2.3). These hypotheses need to be examined with additional data.

Part of the explanation for the lower passage use by deer than would be expected from the surrounding habitat is not that they are avoiding the road, but instead are using old routes that take them over the road. Twenty-three percent of the deer observations along the road transect were of deer skirting the fencing and crossing over the road, while $77 \%$ of the observations were from deer crossing under the bridge. The combination of this large number of over-road deer crossings with those under the bridge yields usage of the road transect comparable to the null expected usage of no difference from the habitat transects. Therefore, the deer did not seem to be avoiding the road transect relative to the surrounding habitat transects.

The majority of the least commonly detected species detections can be explained by habitat variability (Figure 2.2.3 and 3.2.4). Nutria, beaver and blue heron were exclusively or primarily detected at the $25 \mathrm{M}$ north transect, which coincides with meandering waterways. Opossum and skunk show no clear pattern of movement except for a decrease at the $25 \mathrm{M}$ North transect. 
Mallards appeared to prefer locations very near and under the road. Rabbit were only detected at the 100M North transect which is likely explained by the proximity to a forest edge, a preferred habitat type for them. Coyotes are thus far the only species that could be demonstrating an avoidance of the road, though this also may just be a preference for proximity to the forested area. Continued monitoring will increase the sample size of the least frequently detected species and will provide further evidence for or against this study's assumptions.

As planted vegetation matures, the movement of species over the landscape is expected to change. Species that prefer cover should be more likely to use new locations toward the road. Changes in movement patterns due to changes in vegetation are expected to further increase use of the passage structures, perhaps decreasing use of the road for passage. Some of the potential changes in movement patterns have already been detected at the 100M North transect (Figure 3.2.5). The study team documented a shift in deer routes over time that corresponded to a shift in the vegetation at the site. These locations will continue to be monitored to further assess the potential shift and its impact on passage structure use and effectiveness.

The utilization of fencing has no doubt greatly increased the success of the Boeckman Road site. Fencing coupled with adequate passage structures prevents animal-vehicle collisions while maintaining essential habitat connections for wildlife (Clevenger et al. 2001, Dodd et al. 2004, Glista et al. 2009). There was, however, a high proportion of passage by several species, including deer, that occurred over the road instead of by passage structures, despite an amphibian wall topped with deer fencing. The growth of planted vegetation may help to decrease the proportion of over-road passage.

Changing the design or simply extending fencing as well as attracting animals towards the crossings could further enhance the effectiveness of the prevention and passage structures. To increase the effectiveness of the prevention fencing, it would be best to extend the fencing beyond the key habitat (wetland and adjacent wooded habitat). Another method that could be employed to enhance the effectiveness of prevention fencing is the use of vegetation to funnel and/or discourage wildlife movements. For instance, native vegetation plantings could be used to further increase cover and browse along the center of the bridge as well as enhancing habitat on the south side of the bridge. Selecting particular species of native vegetation that animals have an aversion to may have the opposite effect on behavior, and could be used to discourage animals from traveling to fence ends.

In comparison to studies on usage of passages installed as retrofits, species use of passages at Boeckman was instantaneous. Use of passages installed as retrofits typically takes three or more years. In contrast, some passage occurred during construction at the Boeckman extension, and just a year after the road opened almost 1,000 passages across 20 species were detected in a twomonth period for part of the bridge alone. While some species were not evident immediately, species use of habitat and road structures increased as construction concluded and as vegetation has matured.

Oregon's native wildlife faces an ever-increasing urban landscape as well as the potential impacts of climate change (Burns et al. 2003, van der Ree 2005, Mawdsley et al. 2009). Such landscape-level changes highlight the importance of studies of passage and prevention structures as well as the importance of the structures themselves. These data suggest that including a high 
level of passage and prevention structures in a new road, especially if they were modified following the suggestions above, can allow for very high habitat permeability for many species. The overland extension of the bridge provided by far the greatest frequency of crossings and the highest number of species crossing in this study. Therefore the study's results suggest such a structure would provide the best connectivity for wildlife faced with urbanization or movement due to climate change. When maintenance factors, driver safety and species of greatest concern are included, the higher cost of the bridge structure would likely be even further balanced by the benefits. 


\subsection{REFERENCES}

Ascensae, F, and A. Mira. 2007. Factors affecting culvert use by vertebrates along two stretches of road in southern Portugal. Ecological Research 22: 57-66

Burns, C.E., K.M. Johnston, and O.J. Schmitz. 2003. Global climate change and mammalian species diversity in U.S. National Parks. Proceedings of the National Academy of Sciences of the United States of America 100 (20): 11474-11477

Clevenger, A.P. 2005. Conservation Value of Wildlife Crossings: Measures of Performance and Research Directions. GAIA - Ecological Perspectives for Science and Society 14 (2): 124-129

Clevenger, A.P., B. Chruszcz, and K.E. Gunson. 2001. Highway mitigation fencing reduces wildlife-vehicle collisions. Wildlife Society Bulletin 29(2): 646-653

Clevenger, A.P., B. Chruszcz, and K.E. Gunson. 2001. Drainage culverts as habitat linkages and factors affecting passage by mammals. The Journal of Applied Ecology 38(6): 1340-1349

Clevenger, A.P., and N. Waltho. 2000. Factors influencing the effectiveness of wildlife underpasses in Banff National Park, Alberta, Canada. Conservation Biology 14(1): 47-56

CREST. 2007. Center for Research in Environmental Science and Technologies. http://www.crest.wlwv.k12.or.us/

Dodd, Jr., C.K., W.J. Barichivich, and L.L. Smith. 2004. Effectiveness of a barrier wall and culverts in reducing wildlife mortality on a heavily traveled highway in Florida. Biological Conservation 118(5): 619-631

Forman, R.T., D. Sperling, J. Bissonette, A. Clevenger, C. Cutshall, V. Dale, L. Fahrig, R. France, C. Goldman, K. Heanue, J. Jones, F. Swanson, T. Turrentine, and T. Winter, T. 2003. Road Ecology Science and Solutions. Pgs 99 - 167. Washington, DC: Island Press 
Friedman, D.S. 1997. Nature as Infrastructure: The National Ecological Network and Wildlife-Crossing Structures in The Netherlands. Report 138. Wageningen, Netherlands: DLO Winand Staring Centre.

Girvetz, E.H., J.H. Thorne, A.M. Berry, et al. 2008. Integration of landscape fragmentation analysis into regional planning: A statewide multi-scale case study from California, USA. Landscape and Urban Planning 86(3-4): 205-218

Glista, D.J., T.L. DeVault, and J.A. DeWoody. 2007. Vertebrate road mortality predominantly impacts amphibians. Herpetological Conservation and Biology 3(1): $77-87$

Glista, D.J., T.L. DeVault, and J.A. DeWoody. 2009. A review of mitigation measures for reducing wildlife mortality on roadways. Landscape and Urban Planning 91: 1-7

Insurance Institute for Highway Safety (IIHS). 2005. Status Report 40(1). http://www.iihs.org/research/topics/vehicle_animal_collisions.html

Kautz, R., R. Kawula, T. Hoctor, J. Comiskey, D. Jansen, D. Jennings, J Kasbohm, F. Mazzotti, R. McBride, L. Richardson, and K. Root. 2006. How much is enough? Landscape-scale conservation for the Florida panther. Biological Conservation 130: $118-133$

Langen, T., A. Machniak, E. Crowe, C. Mangan, D. Martker, N. Liddle, and Roden. 2007. Methodologies for Surveying Herpetofauna Mortality on Rural Highways. Journal of Wildlife Management. 71: 1361-1368

Langton, T.E.S., ed. 1989. Amphibians and Roads. Shefford, Bedfordshire, England: ACO Polymer Products

Mawdsley, J.R., R. O'Malley, and D.S. Ojima. 2009. A review of climate-change adaptation strategies for wildlife management and biodiversity conservation. Washington, D.C.: The Heinz Center, Society for Conservation Biology.

Ng, S., J. Dole, R. Sauvajot, S. Riley, and T. Valone. 2004. Use of highway undercrossings by wildlife in southern California. Biological Conservation 115: 499-507 
Philcox, C., A. Grogan, and D. MacDonald. 1999. Patterns of otter Lutra lutra road mortality in Britain. The Journal of Applied Ecology 36: 748-762

Shepard, D.B., A.R. Kuhns, M.J. Dreslik, and C.A. Phillips. 2008. Roads as barriers to animal movement in fragmented landscapes. Animal Conservation 11: 288-296

Shilling, F., and E. Girvetz. 2007. Physical and financial barriers to implementing a nature reserve network in the Sierra Nevada. Landscape and Urban Planning 80: $165-172$

Steen, D.A., M.J.Aresco, S.G.Beilke, B.W.Compton, E.P.Condon, C.K. Dodd Jr., H. Forrester, J.W. Gibbons, J.L. Greene, G. Johnson, T.A. Langen, M.J. Oldham, D.N. Oxier, R.A. Saumure, ,F.W. Schueler, J.M. Sleeman, L.L. Smith, J.K. Tucker, and J.P. Gibbs. 2006. Relative vulnerability of female turtles to road mortality. Animal Conservation 9: 269-273

van der Ree R., and M.A. McCarthy. 2005. Inferring persistence of indigenous mammals in response to urbanization. Animal Conservation 8: 309-319 


\section{SO OTREC \\ AND EDUCATION CONSORTIUM}

P.O. Box 751

Portland, OR 97207

OTREC is dedicated to stimulating and conducting collaborative multi-disciplinary research on multi-modal surface transportation issues, educating a diverse array of current practitioners and future leaders in the transportation field, and encouraging implementation of relevant research results. 